\title{
New Approach for Using of Mentha longifolia L. and Citrus reticulata L. Essential Oils as Wood-Biofungicides: GC-MS, SEM, and MNDO Quantum Chemical Studies
}

\author{
Hayssam M. Ali ${ }^{1,2} \mathbb{D}^{D}$, Wael A. A. Abo Elgat ${ }^{3}(\mathbb{D})$, Mervat EL-Hefny ${ }^{4}{ }^{\mathbb{D}}$, Mohamed Z. M. Salem ${ }^{5, *(D)}$, \\ Ayman S. Taha ${ }^{6}{ }^{D}$, Dunia A. Al Farraj ${ }^{1}$, Mohamed S. Elshikh ${ }^{1}$, Ashraf A. Hatamleh ${ }^{1}$ \\ and Eslam M. Abdel-Salam ${ }^{1}$ (D)
}

check for updates

Citation: Ali, H.M.; Elgat, W.A.A.A.; EL-Hefny, M.; Salem, M.Z.M.; Taha, A.S.; Al Farraj, D.A.; Elshikh, M.S.; Hatamleh, A.A.; Abdel-Salam, E.M. New Approach for Using of Mentha longifolia L. and Citrus reticulata $\mathrm{L}$.

Essential Oils as Wood-Biofungicides: GC-MS, SEM, and MNDO Quantum Chemical Studies. Materials 2021, 14, 1361. https://doi.org/10.3390/ ma14061361

Academic Editor: Shin-ichi Kawaguchi

Received: 5 February 2021

Accepted: 8 March 2021

Published: 11 March 2021

Publisher's Note: MDPI stays neutral with regard to jurisdictional claims in published maps and institutional affiliations.

Copyright: (c) 2021 by the authors. Licensee MDPI, Basel, Switzerland. This article is an open access article distributed under the terms and conditions of the Creative Commons Attribution (CC BY) license (https:/ / creativecommons.org/licenses/by/ $4.0 /)$.
1 Botany and Microbiology Department, College of Science, King Saud University, P.O. Box 2455, Riyadh 11451, Saudi Arabia; hayhassan@ksu.edu.sa (H.M.A.); dfarraj@ksu.edu.sa (D.A.A.F.); melshikh@ksu.edu.sa (M.S.E.); ahatamleh@ksu.edu.sa (A.A.H.); 436108002@student.ksu.edu.sa (E.M.A.-S.)

2 Agriculture Research Center, Timber Trees Research Department, Sabahia Horticulture Research Station, Horticulture Research Institute, Alexandria 21526, Egypt

3 Restoration Department, High Institute of Tourism, Hotel Management and Restoration, Abukir, Alexandria 21526, Egypt; watsat20@yahoo.com

4 Department of Floriculture, Ornamental Horticulture and Garden Design, Faculty of Agriculture (El-Shatby), Alexandria University, Alexandria 21545, Egypt; mervat.mohamed@alexu.edu.eg

5 Forestry and Wood Technology Department, Faculty of Agriculture (EL-Shatby), Alexandria University, Alexandria 21545, Egypt

6 Conservation Department, Faculty of Archaeology, Aswan University, Aswan 81528, Egypt; aymansalahtaha82@yahoo.com

* Correspondence: mohamed-salem@alexu.edu.eg

Abstract: Background: Fungi growing on wood cause deterioration of stored food materials or discoloration of the wood itself, and the search for new and safe bioagents is recently needed. Methods: Essential oils (EOs) from aerial parts from Mentha longifolia L. and Citrus reticulata L., analyzed by gas chromatography-mass spectrometry (GC-MS), were tested for their antifungal activity by the vapor method against four common fungi, Aspergillus flavus, A. niger, A. fumigatus, and Fusarium culmorum, and confirmed by SEM examination as the oils applied on wood samples. Results: The most abundant compounds identified in the EO from M. longifolia were menthone and eucalyptol; in C. reticulata EO, they were $\beta$-caryophyllene, $\beta$-caryophyllene oxide, and $\beta$-elemene. EOs from $M$. longifolia and C. reticulata, at 500 and $250 \mu \mathrm{L} / \mathrm{mL}$, showed potent antifungal activity against $A$. flavus and $A$. fumigatus, with $100 \%$ fungal mycelial inhibition growth (FMIG). C. reticulata and $M$. longifolia EOs, at $125 \mu \mathrm{L} / \mathrm{mL}$, observed FMIG values of $98 \%$ and $95 \%$, respectively, against A. fumigatus. M. longifolia EO, at 500 and $250 \mu \mathrm{L} / \mathrm{mL}$, showed potent activity against $A$. niger, with $100 \%$ FMIG. F. culmorum completely inhibited (100\% FMIG) EOs from M. longifolia and C. reticulata applied at $500 \mu \mathrm{L} / \mathrm{mL}$. Pinus roxburghii Sarg. Wood, treated with $M$. longifolia at $125 \mu \mathrm{L} / \mathrm{mL}$, showed inhibition zone values of 7.33 and $21.33 \mathrm{~mm}$ against $A$. flavus and $A$. niger, respectively. Conclusions: Both oils possessed good wood-biofungicide activity with the vapor method, as clearly shown by the SEM examination. These activities suggest their possible use as natural wood preservatives.

Keywords: antifungal activity; essential oils; mass spectrometry; Mentha longifolia; Citrus reticulata; wood-biofungicide; MNDO quantum; fungi

\section{Introduction}

Fungi such as Aspergillus niger, A. flavus, A. fumigatus, Alternaria tenuissima, Colletotrichum gloeosporioides, Fusarium culmorum, Penicillium chrysogenum, Rhizoctonia solani, and Trichoderma harzianum are capable of growing upon a wide range of organic substrates of wood, lignocellulosic materials, and food, which can lead to the deterioration of stored food materials or the discoloration of wood or paper substances [1-11]. Essential oils 
(EOs) - aromatic substances_can be obtained from different plant parts such as leaves, flowers, seeds, fruits, bark, wood, and roots by extraction using steam or hydrodistillation. Some plant EOs have recently been proven to be successful as ecofriendly biocontrol agents, with antibacterial, antifungal, antioxidant, insecticidal, and antiviral properties [12-21], and have potential uses as natural additives and wood-biofungicides [2-4,6,7] and in the food industry, [22-25].

Mentha longifolia L. (or M. lavandulacea Willd. or M. sylvestris L.) has multipurpose use due to antimicrobial, antioxidant, and insecticidal activities [26,27]. Piperitone oxide $(63.58 \%)$ and 1,8-cineole (12.03\%)—oxygenated monoterpenes-were found as the main compounds in the EO of M. longifolia [27], with strong antibacterial activity against Escherichia coli, Pseudomonas aeruginosa, and Salmonella enterica. cis-Piperitone epoxide, piperitenone oxide and pulegone were the main components in M. longifolia ssp. longifolia, and the essential oil showed strong antimicrobial activity against 30 microorganisms [26]. Carvone, limonene, 1,6-dihydrocarveol, 1,8-cineole, trans-dihydrocarvone, $\beta$-bourbonene, germacrene $\mathrm{D}, \beta$-caryophyllene, and bicyclosesquiphellandrene were found as the main compounds from M. longifolia EO collected from five regions of Saudi Arabia [28]. M. longifolia oils from different regions of South Africa showed good antibacterial activity against $S$. aureus and E. coli [29].

In fact, EOs from $M$. longifolia have shown widely variable antimicrobials against S. aureus, Salmonella typhimurium, E. coli, F. oxysporum, A. flavus, A. niger, Microsporum canis, Mucor ramamnianus, Salmonella enteritidis and Klebsiella pneumonia [30-32]. In addition, EOs from species of Mentha including M. longifolia exhibited significant antimicrobial activity against some bacterial and funal strains [33]. Furthermore, the EO from the dried herb showed potent antibacterial activity against Bacillus subtilis, Micrococcus luteus and Enterococcus faecalis [34]. Very strong antibacterial activity against E. coli, Shigella sonei and Micrococcus flavus and significant fungistatic activity against Trichophyton tonsurans and Candida albicans were found from the application of three Mentha species EO, including M. longifolia [35]. The EO of M. longifolia was observed to have higher antibacterial and antifungal activities than tested commercial substances [35]. The main compounds of M. Longifolia EO were piperitenone oxide (70\%), piperitenone (18.7\%) and 1,8-cineole $(2.2 \%)$, and this oil suppressed the growth of $A$. flavus [36]. M. longifolia EO had significant antifungal and antioxidant activities; the main compounds were trans-dihydrocarvone (23.64\%) and piperitone (17.33\%) [31]. Recently, leaf EO, with piperitone and eucalyptol as the main compounds, showed potent antibacterial activity against B. subtilis, S. aureus, $P$. aeruginosa and E. coli [37].

Citrus reticulata L., belonging to the Rutaceae family, is an important fruit citrusbearing plant with an excellent source of EO [38]. Peels of C. reticulata Blanco, with its main compounds of tangeretin, nobiletin, 5-demethylnobiletin, tetramethyl-o-scutellarein, tetramethyl-o-isoscutellarein, pentamethoxyflavone, and sinensetin, was observed to cause potent growth inhibition of $A$. niger [39]. Limonene and other compounds were found to be the major compounds in the EOs extracted from peels, in addition to other constituents such as sabinene, linalool, $\gamma$-terpinene, and methyl $N$-methylanthranilate, which were identified in leaf EO [40]. Generally, the EO from C. reticulata is regarded as safe, with excellent antifungal, antibacterial, and antioxidative properties and usefulness in food and medicine [41]. $\beta$-caryophyllene oxide, the epoxide derivative from $\beta$-caryophyllene, is a component of many EOs, especially C. reticulata [42].

Therefore, the aim of the present study is to evaluate the bioactivity of essential oils from $M$. longifolia aerial parts and C. reticulata leaves against some common molds and to identify the chemical composition of these oils using gas chromatography-mass spectrometry (GC-MS), with semiempirical calculations of molecules for the main compounds. Additionally, we study the effects of those oils as wood-biofungicides by the vapor method and confirm the activity by scanning electron microscope (SEM) examination. 


\section{Materials and Methods}

\subsection{Extraction of Essential Oils}

Aerial parts of Mentha longifolia L. (Saudi cultivar, collected from Riyadh, Saudi Arabia, during April 2019) and leaves of Citrus reticulata L. (collected during March 2019 from Alexandria, Egypt) were used for the extraction. About $150 \mathrm{~g}$ of air-dried plant material from M. longifolia and another $150 \mathrm{~g}$ of fresh leaves from $C$. reticulata were extracted by the hydrodistillation method using a Clevenger apparatus (Local manufacturing shop, Alexandria, Egypt) [21]. The plant materials were inserted in a $2 \mathrm{~L}$ flask with $1.5 \mathrm{~L}$ of distilled water and heated for $3 \mathrm{~h}$ under refluxing [43]. M. longifolia and C. reticulata yielded EOs of $2.5 \%$ and $1.12 \%$, respectively, of the dried material.

\subsection{GC-MS Analysis of Essential Oils}

The chemical constituents of the essential oils were analyzed using a Focus G C-DSQ mass spectrometer (Thermo Scientific, Austin, TX, USA). The apparatus was equipped with a direct capillary column (TG-5MS; $30 \mathrm{~m} \times 0.25 \mathrm{~mm} \times 0.25 \mu \mathrm{m}$ film thickness). The initial temperature of the column oven was held at $45^{\circ} \mathrm{C}$ and then increased to $200^{\circ} \mathrm{C}$ at $5{ }^{\circ} \mathrm{C} / \mathrm{min}$ and held for $5 \mathrm{~min}$. The temperature was then increased to $300{ }^{\circ} \mathrm{C}$, with 30 increments of $5{ }^{\circ} \mathrm{C} / \mathrm{min}$ [44]. All the compounds were identified using their retention times and mass spectra by matching them with those from WILEY 09 and NIST 11 mass spectral databases. Standard Index and Reverse Standard Index measurements, with the Xcalibur 3.0 data system (3.0, Thermo Fisher Scientific Inc., Austin, TX, USA, 2014) of GC/MS, were used to confirm the identification of the compounds, where a value $\geq 650$ is acceptable to confirm the compounds $[6,7,15-20,45]$.

\subsection{Fungal Isolates, the Antifungal Activity Method and the Application on Wood}

Fungi of Aspergillus flavus AFl375, A. niger Ani245, A. fumigatus Afu694, and Fusarium culmorum Fcu761, with their accession numbers of MH355958, MH355955, MH355959 and MH355954, were used for the bioassay evaluation. All the fungal isolates were identified using a partial ITS gene [9]. The EOs were prepared at the concentrations of 500, 250, 125, and $65 \mu \mathrm{L} / \mathrm{mL}$ by dilution in $10 \%$ dimethyl sulfoxide (DMSO); a few drops of Tween 80 $(0.01 \%)$ were added based on potato dextrose agar (PDA) medium. Tests of inhibition of microorganisms were performed in $9 \mathrm{~cm}$ Petri dishes with PDA, with and without the EOs. For comparisons, the standard antibiotic of Sertaconazol $3 \mathrm{~g} / \mathrm{L}$ as a positive and $10 \% \mathrm{DMSO}$, with Tween 80 as negative control, was used. Each treatment was evaluated in triplicate. Seven-day-old colonies from each fungus, measuring $9 \mathrm{~mm}$, were put in the center of the treated PDA dishes and controls and incubated at $26 \pm 1{ }^{\circ} \mathrm{C}$ for 14 days. When the mycelial fungus growth completely filled the Petri dish in the control treatment (negative), the fungal mycelial inhibition growth (FMIG) percentage was calculated as follows: FMIG\% $=[(\mathrm{AC}-$ $\mathrm{AT}) / \mathrm{AC}] \times 100$, where AC and AT represent the average diameters of the fungal colony of the control and treatment, respectively $[46,47]$. The lowest two concentrations were used for the application on wood samples of Pinus roxburghii Sarg. to show their activity as wood-biofungicides using vapor treatment [48-50].

\subsection{SEM Examination of Inoculated Wood}

Scanning electron microscope (SEM) examination was used to show the fungal growth on $P$. roxburghii wood samples that were treated and untreated with oils and inoculated with each of the four molds using the JFC-1100E ion sputtering device (model JSM-5300, JEOL, Tokyo, Japan) at $8 \mathrm{kV}[8,9,11,51]$.

\subsection{Computation Method}

Based on semiempirical calculations, geometry optimization of the studied molecules was done using the molecular modeling program Hyperchem7.5 (W.Thiel 2003, HyperChemTM, Release 7.5 Pro 2002, Athens, GA, USA). Semiempirical calculations were carried 
out using the routine Modified Neglect of Diatomic Overlap (MNDO) and Polak-Ribiere conjugated gradient algorithm, as shown in previous works $[18,52,53]$.

\subsection{Statistical Analysis}

The mycelial inhibition growth percentage values were statistically analyzed for two factors (EO type and EO concentration) using analysis of variance and the Statistical Analysis Software (SAS, Release 8.02, Cary, NC, USA) system [54]. Differences among means were measured using Duncan's multiple range test at alpha $<0.05$.

\section{Results}

\subsection{Essential Oil Composition}

Figure 1a,b shows the GC/MS chromatograms of the separated chemical compounds in the essential oils (EOs) from aerial parts of M. longifolia and leaves of $C$. reticulata, respectively. Table 1 presents the chemical composition of the EO from M. longifolia aerial parts, from which 8 compounds were identified. The main constituents were menthone $(48.00 \%)$, eucalyptol $(21.66 \%)$, and pulegone $(12.09 \%)$. Table 2 presents the chemical compounds of the EO from C. reticulata aerial parts, which were composed of $48 \mathrm{com}$ pounds, where the main compounds were $\beta$-caryophyllene (15.57\%), $\beta$-caryophyllene oxide $(7.04 \%)$, $\beta$-elemene $(6.39 \%), \gamma$-elemene $(5.62 \%)$, $\beta$-bisabolene $(4.86 \%)$, spathulenol $(4.74 \%), \alpha$-caryophyllene $(4.53 \%)$, longifolene $(4.40 \%), \gamma$-gurjunene $(3.74 \%)$, geranyl acetate $(3.34 \%), \alpha$-bergamotene $(3.19 \%)$, linalyl acetate $(2.96 \%)$, germacrene $\mathrm{D}(2.28 \%)$, nerol $(2.24 \%)$, D-limonene $(2.14 \%)$, and geraniol $(2.00 \%)$.
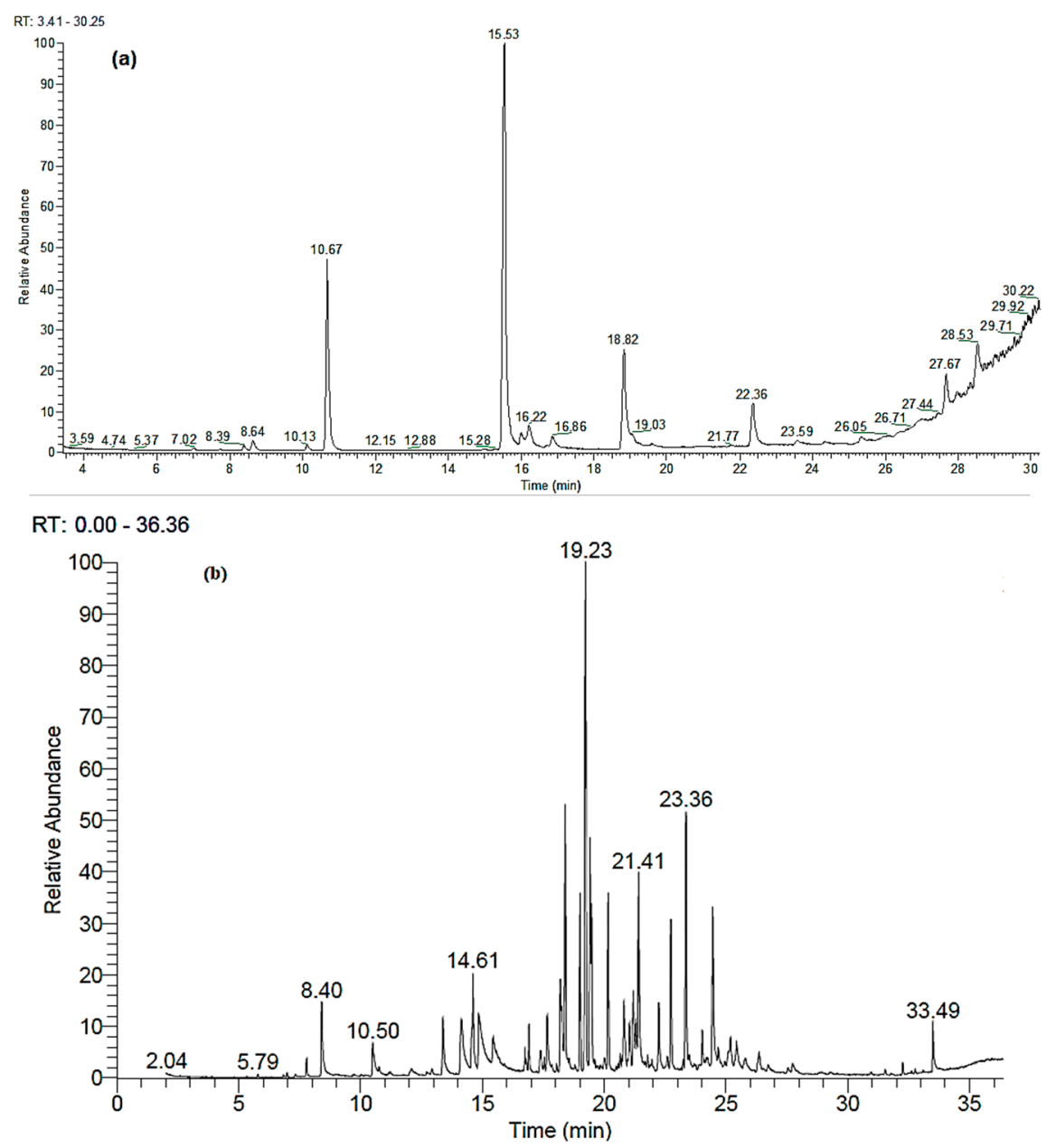

Figure 1. Gas chromatography-mass spectrometry (GC-MS) separation chromatograms for the essential oils from aerial parts of (a) M. longifolia and (b) C. reticulata. R.T. (Retention time, min). 
Table 1. Chemical composition of the essential oil from Mentha longifolia aerial parts.

\begin{tabular}{cc}
\hline Compound Name & Percentage in the Oil (\%) \\
\hline Eucalyptol or 1,8-cineole & $21.66(946-947))^{*}$ \\
Menthone & $48.00(946-969)$ \\
Borneol & $2.10(885-910)$ \\
Pulegone & $12.09(917-934)$ \\
$\beta$-Caryophyllene & $5.57(910-938)$ \\
2-Methylene-5 $\alpha$-cholestan-3 $\beta$-ol & $4.89(812-845)$ \\
1-Heptatriacotanol & $5.69(767-777)$ \\
\hline Oxygenated Monoterpenes & 83.85 \\
Sesquiterpenes & 5.57 \\
Pentacyclic triterpenes & 4.89 \\
Fatty alcohol (\%) & 5.69 \\
\hline
\end{tabular}

* Values in parentheses are Standard Index (SI) and Reverse Standard Index (RSI).

Table 2. Chemical composition of the essential oil from Citrus reticulata leaves.

\begin{tabular}{|c|c|}
\hline Compound Name & Percentage in the Oil (\%) \\
\hline$\Delta$-3-Carene & $0.41(922-937) *$ \\
\hline D-Limonene & $2.14(923-925)$ \\
\hline Linalool & $1.12(943-954)$ \\
\hline Citronellal & $0.50(883-902)$ \\
\hline Terpinen-4-ol & 0.17 (879-882) \\
\hline$\alpha$-Terpineol & $1.70(938-940)$ \\
\hline Nerol & $2.24(862-887)$ \\
\hline Linalyl acetate & $2.96(885-889)$ \\
\hline Geraniol & 2.00 (929-935) \\
\hline Citral & $1.41(888-901)$ \\
\hline$\Delta$-Elemene & $1.65(854-897)$ \\
\hline Isopulegol acetate & $0.89(782-843)$ \\
\hline$\gamma$-Muurolene & $0.24(836-855)$ \\
\hline Neryl acetate & $1.63(926-932)$ \\
\hline$\alpha$-Himachalene & $0.17(870-887)$ \\
\hline Geranyl acetate & $3.34(902-936)$ \\
\hline$\beta$-Elemene & 6.39 (934-938) \\
\hline Longifolene & $4.40(958-958)$ \\
\hline$\beta$-Caryophyllene & 15.57 (945-946) \\
\hline$\gamma$-Elemene & $5.62(945-947)$ \\
\hline$\alpha$-Bergamotene & 3.19 (933-955) \\
\hline Nerolidol & $0.40(760-777)$ \\
\hline$\alpha$-Caryophyllene & $4.53(935-945)$ \\
\hline Ylangene & $0.23(838-862)$ \\
\hline Germacrene D & $2.28(924-935)$ \\
\hline$\beta$-Selinene & $1.34(928-959)$ \\
\hline$\alpha$-Selinene & $1.88(943-958)$ \\
\hline$\alpha$-Farnesene & $0.69(917-945)$ \\
\hline$\beta$-Bisabolene & $4.86(928-942)$ \\
\hline Selina-3,7(11)-diene & $0.25(859-881)$ \\
\hline cis-Z- $\alpha$-Bisabolene epoxide & $0.36(810-817)$ \\
\hline trans-Longipinocarveol & $1.86(802-810)$ \\
\hline Caryophyllene oxide & $0.43(856-901)$ \\
\hline$\gamma$-Gurjunene & $3.74(895-911)$ \\
\hline$\beta$-Caryophyllene oxide & 7.04 (954-956) \\
\hline Isoaromadendrene epoxide & $0.17(798-847)$ \\
\hline Humulene oxide II & $0.85(818-901)$ \\
\hline Alloaromadendrene & $0.12(799-860)$ \\
\hline Nerolidol-epoxyacetate & 0.17 (799-853) \\
\hline Spathulenol & $4.74(883-884)$ \\
\hline
\end{tabular}


Table 2. Cont.

\begin{tabular}{cc}
\hline Compound Name & Percentage in the Oil (\%) \\
\hline Globulol & $1.46(839-871)$ \\
Guaiene & $0.91(831-842)$ \\
2-Methylene-5 $\alpha$-cholestan-3 $\beta$-ol & $0.47(789-811)$ \\
Ledene oxide-(II) & $0.34(824-842)$ \\
Squalene & $0.30(708-716)$ \\
Urs-12-en-28-ol & $1.13(736-787)$ \\
\hline Monoterpene hydrocarbons & 2.59 \\
Oxygenated monoterpenes & 18.27 \\
Sesquiterpene hydrocarbons & 59.07 \\
Oxygenated sesquiterpenes & 18.13 \\
Pentacyclic triterpenes & 1.62 \\
Triterpene hydrocarbon & 0.30 \\
\hline
\end{tabular}

* Values in parentheses are Standard Index (SI) and Reverse Standard Index (RSI).

\subsection{Thermodynamic Data for the Most Abundant Essential Oil Compounds}

In this study, the main components in the two studied samples were divided into two groups. In the first group (Group I) were the compounds containing an oxygen atom in a single or double bond in their structures, namely, eucalyptol, menthone, pulegone, and $\beta$-caryophyllene oxide. In the second group (Group II) were the compounds containing no oxygen atom in their structures, which included $\beta$-caryophyllene and $\gamma$-elemene. Table 3 shows all thermodynamic data calculated using Modified Neglect of Diatomic Overlap (MNDO) semiempirical calculations. From the calculated data of the studied molecules (Table 3), one can observe that the negative values of the heat of formations $(\Delta \mathrm{F}(\mathrm{M}))$ and total energy for Group I (eucalyptol, menthone, pulegone, and caryophyllene oxide) neutral molecules have negative values, which means these molecules are stable; the menthone molecule is the most stable. This is due to the presence of an oxygen atom (single or double bond) in their structures, while Group II $\beta$-caryophyllene and $\gamma$-elemene have positive values of heat of formations ( 12 and $47 \mathrm{Kcal} / \mathrm{mol}$, respectively). From these values, the second group is relatively less stable than the first group, which has oxygen atoms in the structure of its compounds. This is confirmed by the values of dipole moment; hence, the first group has higher values of dipole moment $(1.384,2.446,2.497$, and 1.684) in comparison with the second group (0.133 and 0.158). In addition, one can observe that Group I has higher values of ionization energies $(9.4,9.5,9.0$, and $8.8 \mathrm{eV})$ in comparison with Group II (8.7 and $8.8 \mathrm{eV})$. These due to the higher stability of Group I. The same was observed for electron affinity values: Group I had higher values of EA, as shown in Table 3.

Table 3. Thermodynamic data of the studied molecules, calculated within the modified neglect of the diatomic overlap (MNDO) framework.

\begin{tabular}{|c|c|c|c|c|c|c|c|}
\hline Compound & $\begin{array}{c}\text { Total Energy } \\
\text { (TE) } \\
\text { (Kcal/mol) }\end{array}$ & $\begin{array}{c}\Delta H_{\mathrm{f}}[\mathrm{M}] \\
(\mathrm{Kcal} / \mathrm{mol})\end{array}$ & $\begin{array}{c}\Delta \mathrm{H}_{\mathrm{f}}[\mathrm{M}]^{+\bullet} \\
(\mathrm{Kcal} / \mathrm{mol})\end{array}$ & $\begin{array}{c}\Delta_{\mathrm{f}}[\mathrm{M}]^{-1} \\
(\mathrm{Kcal} / \mathrm{mol})\end{array}$ & $\begin{array}{l}\text { Dipole } \\
\text { Moment } \\
\text { (Debye) }\end{array}$ & $\begin{array}{c}\text { Ionization } \\
\text { Energy (IE) * } \\
\text { eV }\end{array}$ & $\begin{array}{l}\text { Electron Affinity } \\
\text { (EA) }{ }^{* *} \\
\text { eV }\end{array}$ \\
\hline Eucalyptol & $-42,819$ & -52 & 166 & -31 & 1.384 & 9.4 & 0.91 \\
\hline Menthone & $-42,831$ & -64 & 156 & -67 & 2.446 & 9.5 & 0.13 \\
\hline Pulegone & $-42,164$ & -50 & 156 & -71 & 2.497 & 9.0 & 0.91 \\
\hline$\beta$-Caryophyllene oxide & $-59,481$ & -5 & 199 & -3 & 1.684 & 8.8 & 0.08 \\
\hline$\beta$-Caryophyllene & $-52,074$ & 12 & 213 & 11 & 0.133 & 8.7 & 0.04 \\
\hline$\gamma$-Elemene & $-52,039$ & 47 & 252 & 49 & 0.158 & 8.8 & 0.08 \\
\hline
\end{tabular}

${ }^{*}$ The values of ionization energies (IE) were calculated with the following equation: IE $[\mathrm{M}]=\Delta \mathrm{H}_{\mathrm{f}}[\mathrm{M}]^{+\bullet}-\Delta \mathrm{H}_{\mathrm{f}}[\mathrm{M}]$, where $\Delta \mathrm{H}_{\mathrm{f}}[\mathrm{M}]^{+\bullet}$ and $\Delta \mathrm{H}_{\mathrm{f}}[\mathrm{M}]$ are the heat of formation of the molecular ion and neutral molecule, respectively. ${ }^{* *}$ The values of the electron affinity (EA) were calculated with the following equation: EA $[\mathrm{M}]=\Delta \mathrm{H}_{\mathrm{f}}[\mathrm{M}]-\Delta \mathrm{H}_{\mathrm{f}}[\mathrm{M}]^{-1}$, where $\Delta \mathrm{H}_{\mathrm{f}}[\mathrm{M}]^{-1}$ and $\Delta \mathrm{H}_{\mathrm{f}}[\mathrm{M}]$ are the heat of formation of the anion and neutral molecule, respectively. 


\subsection{Antifungal Activity of the Essential Oils}

The inhibition of fungal mycelia correlates positively with concentration (Figures S1-S4).

Table 4 shows the antifungal activity of EOs from $M$. longifolia and C. reticulata against the growth of A.flavus, A. niger, A. terreus, and F. culmorum. For M. longifolia and C. reticulata EOs, at the concentrations of 500 and $250 \mu \mathrm{L} / \mathrm{mL}$, antifungal activity was observed against A. flavus and A. fumigatus, with $100 \%$ fungal mycelial inhibition growth (FMIG), which was higher than the FMIG values from Sertaconazol ( $91 \%$ and $88.66 \%$, respectively). C. reticulata and M. longifolia EOs, at $125 \mu \mathrm{L} / \mathrm{mL}$, showed activity against the growth of A. fumigatus, with FMIG values of $98 \%$ and $95 \%$, respectively. M. longifolia EO, at 500 and $250 \mu \mathrm{L} / \mathrm{mL}$, showed $100 \%$ FMIG against $A$. niger, while C. reticulata EO showed FMIG values of $100 \%$ and $97 \%$, at 500 and $250 \mu \mathrm{L} / \mathrm{mL}$, respectively, which were higher than the value from Sertaconazol (87\%). The EOs from M. longifolia and C. reticulata completely inhibited the growth of F. culmorum, with $100 \%$ FMIG at the concentration of $500 \mu \mathrm{L} / \mathrm{mL}$, which is higher than the value from Sertaconazol (88.33\%). Additionally, at the concentration of $250 \mu \mathrm{L} / \mathrm{mL}$, the EO from C. reticulata showed activity against F. culmorum (FMIG value of $85.66 \%$ ). Furthermore, EOs at lower concentrations (65 and $125 \mu \mathrm{L} / \mathrm{mL}$ ) showed FMIG percentages against the studied molds. Therefore, those two concentrations were used for the application on wood by the vapor method.

Table 4. Inhibition percentage of the diameter growth of A. flavus, A. niger, A. terreus, and F. culmorum, as affected by essential oils (EOs) from Mentha longifolia and Citrus reticulata.

\begin{tabular}{|c|c|c|c|c|c|}
\hline \multirow[b]{2}{*}{ Oil Source } & \multirow{2}{*}{$\begin{array}{c}\text { Concentration } \\
(\mu \mathrm{L} / \mathrm{mL})\end{array}$} & \multicolumn{4}{|c|}{ Inhibition Percentage of Diameter Growth (\%) } \\
\hline & & $\begin{array}{l}\text { Aspergillus } \\
\text { flavus }\end{array}$ & $\begin{array}{l}\text { Aspergillus } \\
\text { fumigatus }\end{array}$ & $\begin{array}{c}\text { Aspergillus } \\
\text { niger }\end{array}$ & $\begin{array}{l}\text { Fusarium } \\
\text { culmorum }\end{array}$ \\
\hline \multirow{4}{*}{ Mentha longifolia } & 65 & $48 \pm 3.46$ & $70 \pm 2.64$ & $63 \pm 2$ & $46.66 \pm 1.15$ \\
\hline & 125 & $74.33 \pm 1.52$ & $95 \pm 1$ & $73.33 \pm 1.52$ & $70 \pm 1$ \\
\hline & 250 & 100 & 100 & 100 & $73.33 \pm 3.21$ \\
\hline & 500 & 100 & 100 & 100 & 100 \\
\hline \multirow{4}{*}{ Citrus reticulata } & 65 & $86.33 \pm 0.57$ & $68.66 \pm 3.05$ & $65.33 \pm 1.52$ & $65.66 \pm 1.15$ \\
\hline & 125 & $91 \pm 3.61$ & $98 \pm 3.46$ & $93.66 \pm 0.57$ & $81 \pm 3$ \\
\hline & 250 & 100 & 100 & $97 \pm 2.64$ & $85.66 \pm 0.57$ \\
\hline & 500 & 100 & 100 & 100 & 100 \\
\hline Negative control (DMSO) & $10 \%$ & 0.00 & 0.00 & 0.00 & 0.00 \\
\hline Sertaconazol & $3 \mathrm{~g} / \mathrm{L}$ & $91 \pm 1$ & $88.66 \pm 1.15$ & $87 \pm 1$ & $88.33 \pm 1.52$ \\
\hline$p$-value & & ** & $* *$ & $* *$ & $* *$ \\
\hline
\end{tabular}

Values are means $\pm \mathrm{SE} .{ }^{* *}$ Highly significant at 0.01 level of probability.

\subsection{Application of Oils on Wood Samples}

Figure 2 shows that both oils from M. longifolia and C. reticulata, at $125 \mu \mathrm{L} / \mathrm{mL}$, showed inhibition zone (IZ) values around the treated Pinus roxburghii wood samples compared to the control treatment (wood without oils), where the growth of fungi was observed. Table 5 presents the antifungal activity of both oils as wood-biofungicides by measuring the growth on wood samples and the IZs around the wood. M. longifolia, applied to wood at $125 \mu \mathrm{L} / \mathrm{mL}$, showed an IZ value of $7.33 \mathrm{~mm}$ against the growth of $A$. flavus. An IZ value of $15.33 \mathrm{~mm}$ was shown for wood treated with C. reticulata oil at $125 \mu \mathrm{L} / \mathrm{mL}$ against A. fumigatus. M. longifolia, at 65 and $125 \mu \mathrm{L} / \mathrm{mL}$, showed potent antifungal activity against A. niger when applied to wood samples with IZ values of 8 and $21.33 \mathrm{~mm}$, respectively. Wood treated with C. reticulata and M. longifolia, at $125 \mu \mathrm{L} / \mathrm{mL}$, showed IZ values of 3.66 and $2.33 \mathrm{~mm}$, respectively, against the growth of F. culmorum. 


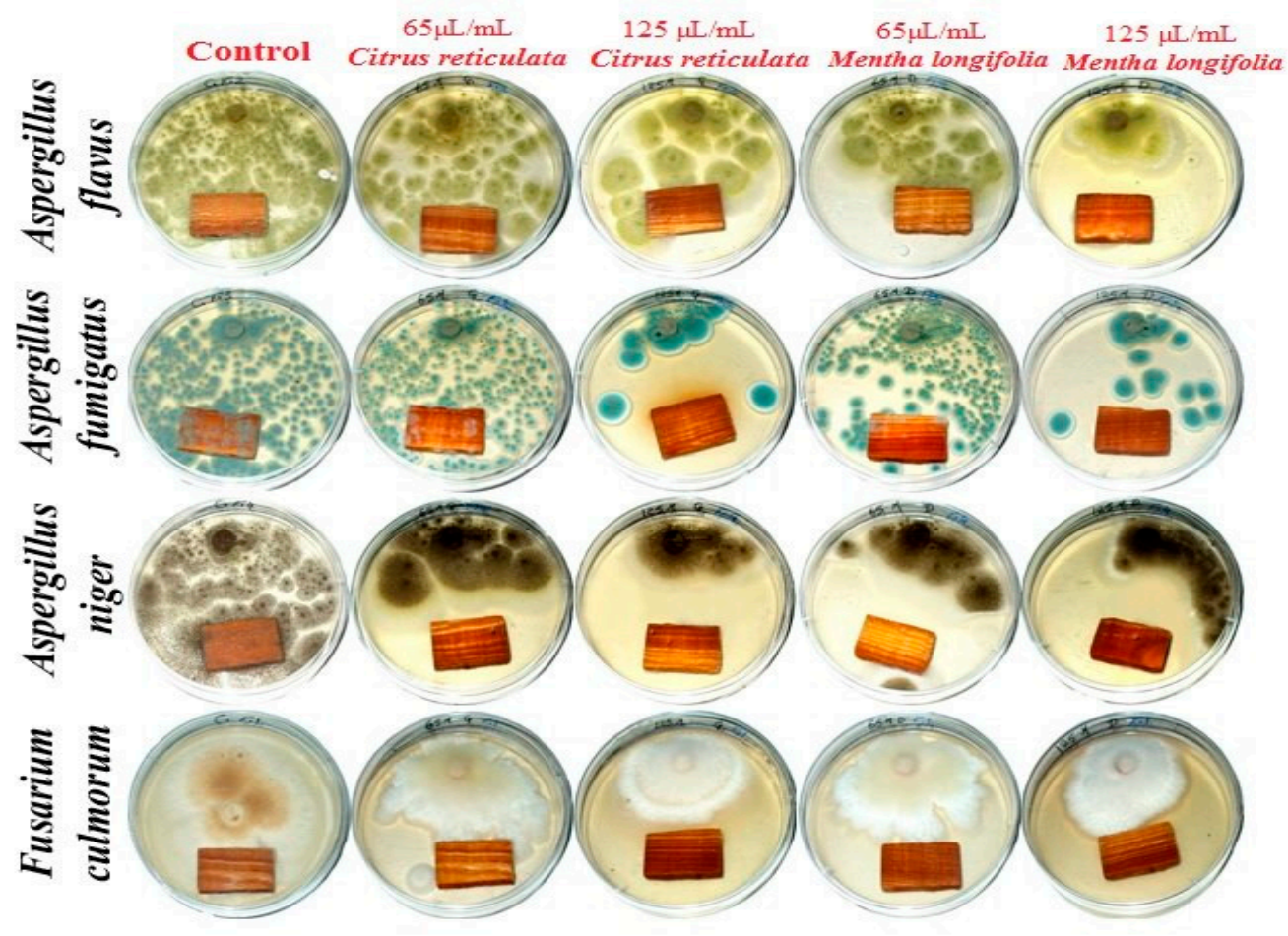

Figure 2. Experimental application of essential oils from Mentha longifolia and Citrus reticulata to Pinus halepensis wood and the visual observation of growth of A.flavus, A. niger, A. terreus, and F. culmorum.

Table 5. Growth on wood samples ** and inhibition zones ** $(\mathrm{mm})$ of A. flavus, A. niger, A. terreus, and F. culmorum, as affected by essential oils from Mentha longifolia and Citrus reticulate.

\begin{tabular}{|c|c|c|c|c|c|c|c|c|c|}
\hline \multirow[b]{2}{*}{ Oil Source } & \multirow[b]{2}{*}{$\begin{array}{c}\text { Concentration } \\
\mu \mathrm{L} / \mathrm{mL}\end{array}$} & \multicolumn{2}{|c|}{ Aspergillus flavus } & \multicolumn{2}{|c|}{ Aspergillus fumigatus } & \multicolumn{2}{|c|}{ Aspergillus niger } & \multicolumn{2}{|c|}{ Fusarium culmorum } \\
\hline & & $\begin{array}{c}\text { Growth on } \\
\text { Sample } \\
(\mathrm{mm})\end{array}$ & IZ (mm) & $\begin{array}{c}\text { Growth on } \\
\text { Sample } \\
(\mathrm{mm})\end{array}$ & IZ (mm) & $\begin{array}{c}\text { Growth on } \\
\text { Sample } \\
(\mathrm{mm})\end{array}$ & IZ (mm) & $\begin{array}{l}\text { Growth on } \\
\text { Sample } \\
(\mathrm{mm})\end{array}$ & IZ (mm) \\
\hline Control & 0 & $20 \pm 0.00$ & 0.00 & 20 & 0.00 & 20 & 0.00 & $18.33 \pm 0.88$ & 0.00 \\
\hline C. reticulata & $\begin{array}{c}65 \\
125\end{array}$ & $\begin{array}{l}0.00 \\
0.00\end{array}$ & $\begin{array}{l}0.33 \pm 0.33 \\
0.66 \pm 0.33\end{array}$ & $\begin{array}{c}5.66 \pm 1.20 \\
0.00\end{array}$ & $\begin{array}{c}0.00 \\
15.33 \pm 3.75\end{array}$ & $\begin{array}{l}0.00 \\
0.00\end{array}$ & $\begin{array}{l}2.33 \pm 0.33 \\
5.33 \pm 0.88\end{array}$ & $\begin{array}{l}0.00 \\
0.00\end{array}$ & $\begin{array}{c}1 \pm 0.57 \\
3.66 \pm 0.88\end{array}$ \\
\hline M. longifolia & $\begin{array}{c}65 \\
125\end{array}$ & $\begin{array}{l}0.00 \\
0.00\end{array}$ & $\begin{array}{l}0.66 \pm 0.33 \\
7.33 \pm 1.20\end{array}$ & $\begin{array}{c}2 \pm 0.57 \\
0.0000\end{array}$ & $\begin{array}{c}0.00 \\
3.33 \pm 0.88\end{array}$ & $\begin{array}{l}0.00 \\
0.00\end{array}$ & $\begin{array}{c}8.00 \pm 2.00 \\
21.33 \pm 5.69\end{array}$ & $\begin{array}{l}0.00 \\
0.00\end{array}$ & $\begin{array}{c}1 \pm 0.57 \\
2.33 \pm 1.45\end{array}$ \\
\hline$p$-value & & $* *$ & $* *$ & ** & ** & $* *$ & ** & ** & $* *$ \\
\hline
\end{tabular}

Values are means \pm SE. ${ }^{* *}$ Highly significant at 0.01 level of probability.

\subsection{SEM Examination of Inoculated Wood with Fungi}

As shown in the SEM images (Figure 3), fungal mycelia growth (FMG) of F. culmorum was observed over P. roxburghii wood samples without treatment (Figure 3a,b) and treated with $65 \mu \mathrm{L} / \mathrm{mL}$ C. reticulata EO (Figure 3c). In contrast, FMG was inhibited or suppressed when the wood was treated with $125 \mu \mathrm{L} / \mathrm{mL}$ C. reticulata EO (Figure 3d), where the wood structures, such as tracheids and pits, are clearly shown with no fungal biomass.

SEM images in Figure 4 clearly show the growth of A. flavus over P. roxburghii wood samples without treatment (Figure $4 \mathrm{a}$ ), treated with $125 \mu \mathrm{L} / \mathrm{mL}$ of C. reticulata $\mathrm{EO}$ (Figure $4 \mathrm{~b}$ ), treated with $65 \mu \mathrm{L} / \mathrm{mL}$ of $M$. longifolia $\mathrm{EO}$ (Figure $4 \mathrm{c}$ ), and treated with $125 \mu \mathrm{L} / \mathrm{mL}$ M. longifolia EO (Figure 4d). FMG was reduced when P. roxburghii wood samples were treated with $65 \mu \mathrm{L} / \mathrm{mL} M$. longifolia $\mathrm{EO}$ (Figure 4e), and FMG was inhibited when the wood samples were treated with $125 \mu \mathrm{L} / \mathrm{mL}$ M. longifolia EO (Figure $4 \mathrm{f}$ ), where tracheids and wood rays are clearly shown.

Additionally, in Figure 5, the SEM images of P. roxburghii wood samples inoculated with $A$. fumigatus showed a high level of fungal growth without treatment (Figure 5a), with $65 \mu \mathrm{L} / \mathrm{mL}$ C. reticulata $\mathrm{EO}$ (Figure $5 \mathrm{~b}$ ), and with $65 \mu \mathrm{L} / \mathrm{mL}$ M. longifolia EO (Figure 5c). 
Significantly, the wood treated with $125 \mu \mathrm{L} / \mathrm{mL}$ M. longifolia EO showed complete inhibition of A. fumigatus fungal growth (Figure $5 \mathrm{~d}$ ); the anatomical features from tracheids and bordered pits are clearly shown.

SEM images in Figure 6 clearly show the high level of growth of A. niger over P. roxburghii wood samples without treatment (Figure $6 \mathrm{a}, \mathrm{b}$ ) and with $65 \mu \mathrm{L} / \mathrm{mL}$ M. longifolia EO (Figure 6c); significant reduction and inhibition of fungal growth were observed when wood samples were treated with $125 \mu \mathrm{L} / \mathrm{mL}$ M. longifolia EO (Figure 6d), where pits and tracheids are shown without fungal penetrations.
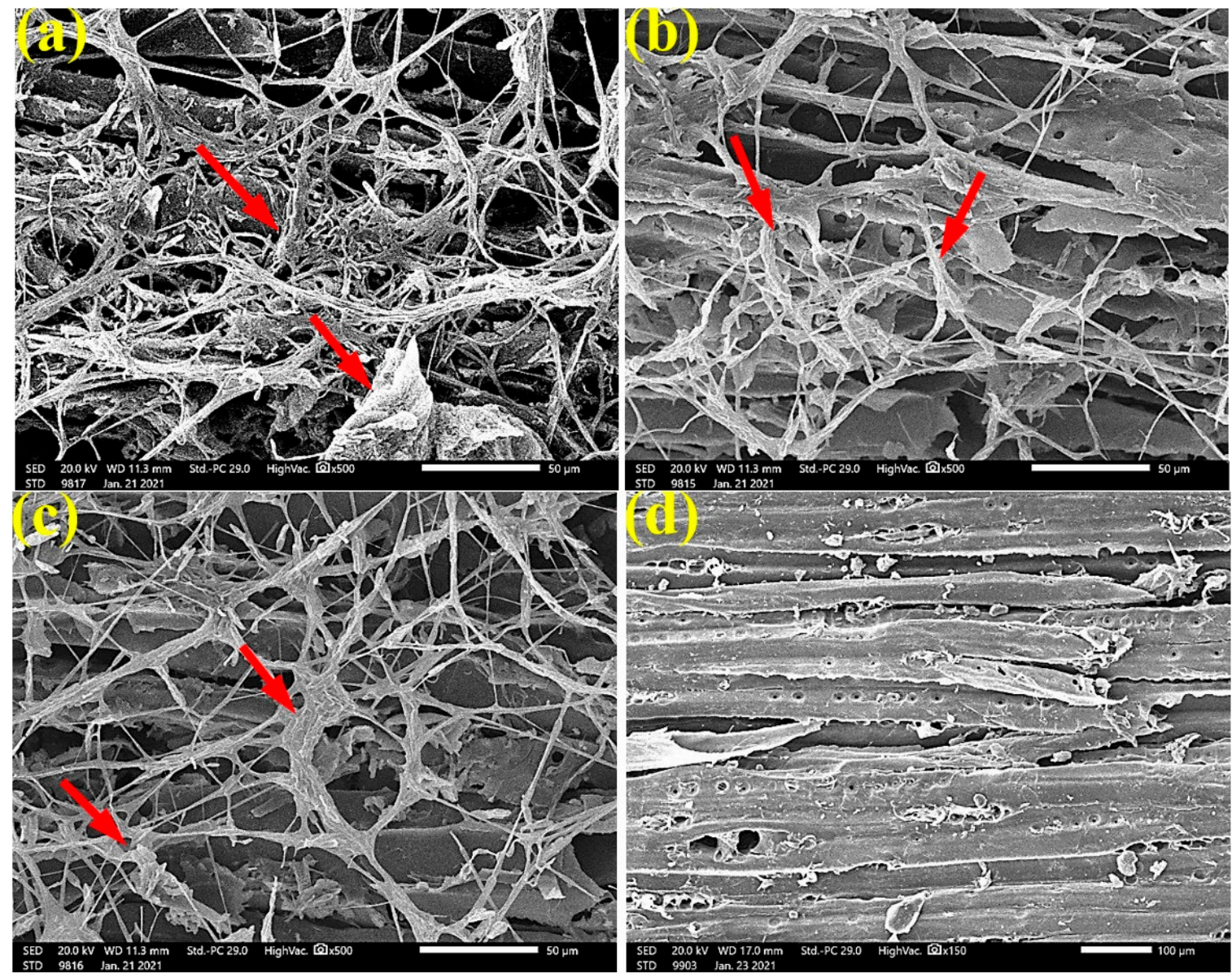

Figure 3. SEM images of $P$. roxburghii wood samples inoculated with F. culmorum: (a,b) without treatment; (c) with $65 \mu \mathrm{L} / \mathrm{mL}$ C. reticulata EO; (d) with $125 \mu \mathrm{L} / \mathrm{mL}$ C. reticulata EO. Arrows refer to the growth of fungal mycelia in wood samples, according to treatment. 

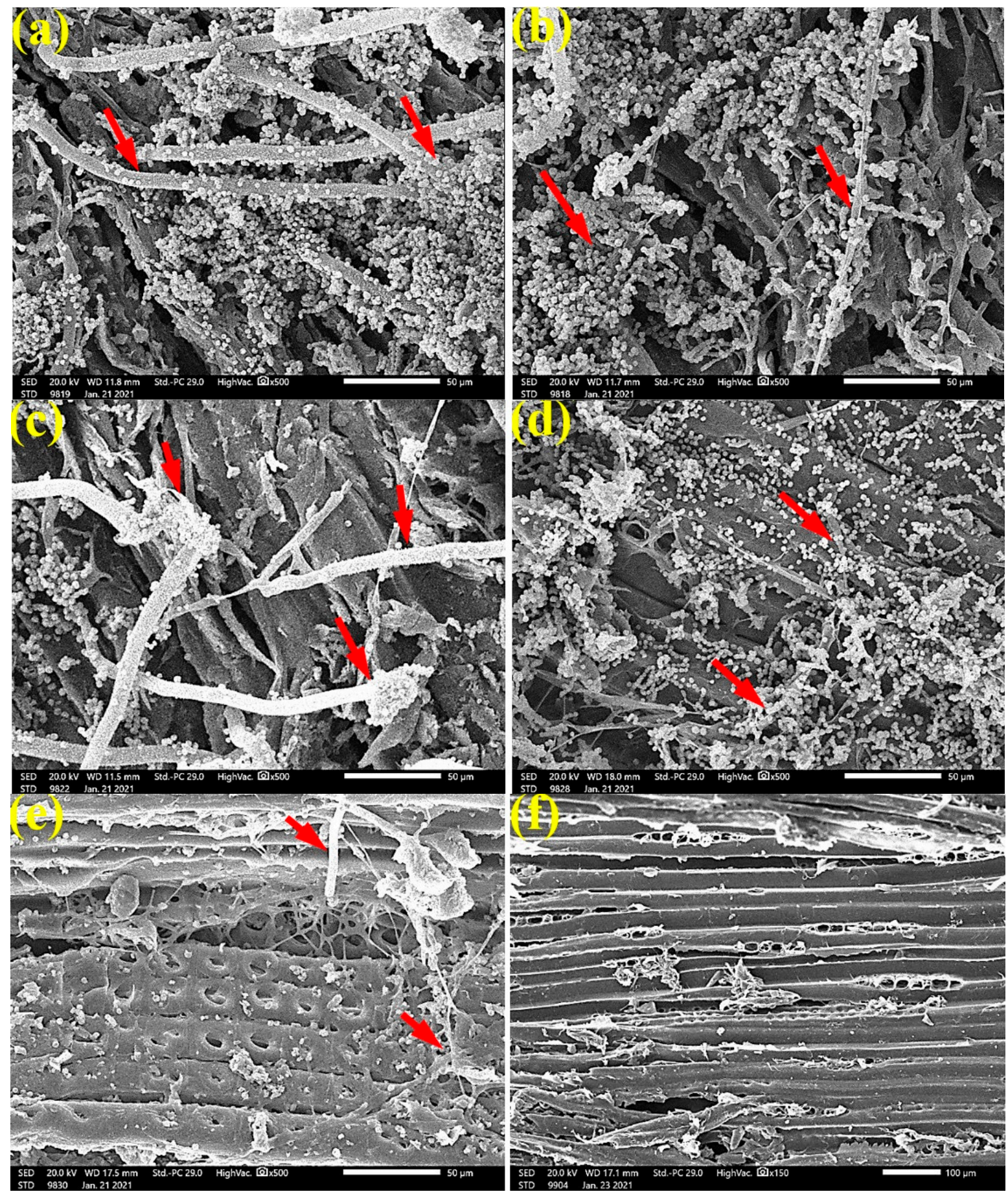

Figure 4. SEM images of $P$. roxburghii wood samples inoculated with A. flavus: (a) without treatment; (b) with $125 \mu \mathrm{L} / \mathrm{mL}$ C. reticulata EO; (c) with $65 \mu \mathrm{L} / \mathrm{mL}$ M. longifolia EO; (d) with $125 \mu \mathrm{L} / \mathrm{mL}$ M. longifolia EO; (e) with $65 \mu \mathrm{L} / \mathrm{mL}$ M. longifolia $\mathrm{EO} ;(\mathbf{f})$ with $125 \mu \mathrm{L} / \mathrm{mL}$ M. longifolia EO. Arrows refer to the dense growth of fungal mycelia in wood samples, according to treatment. 

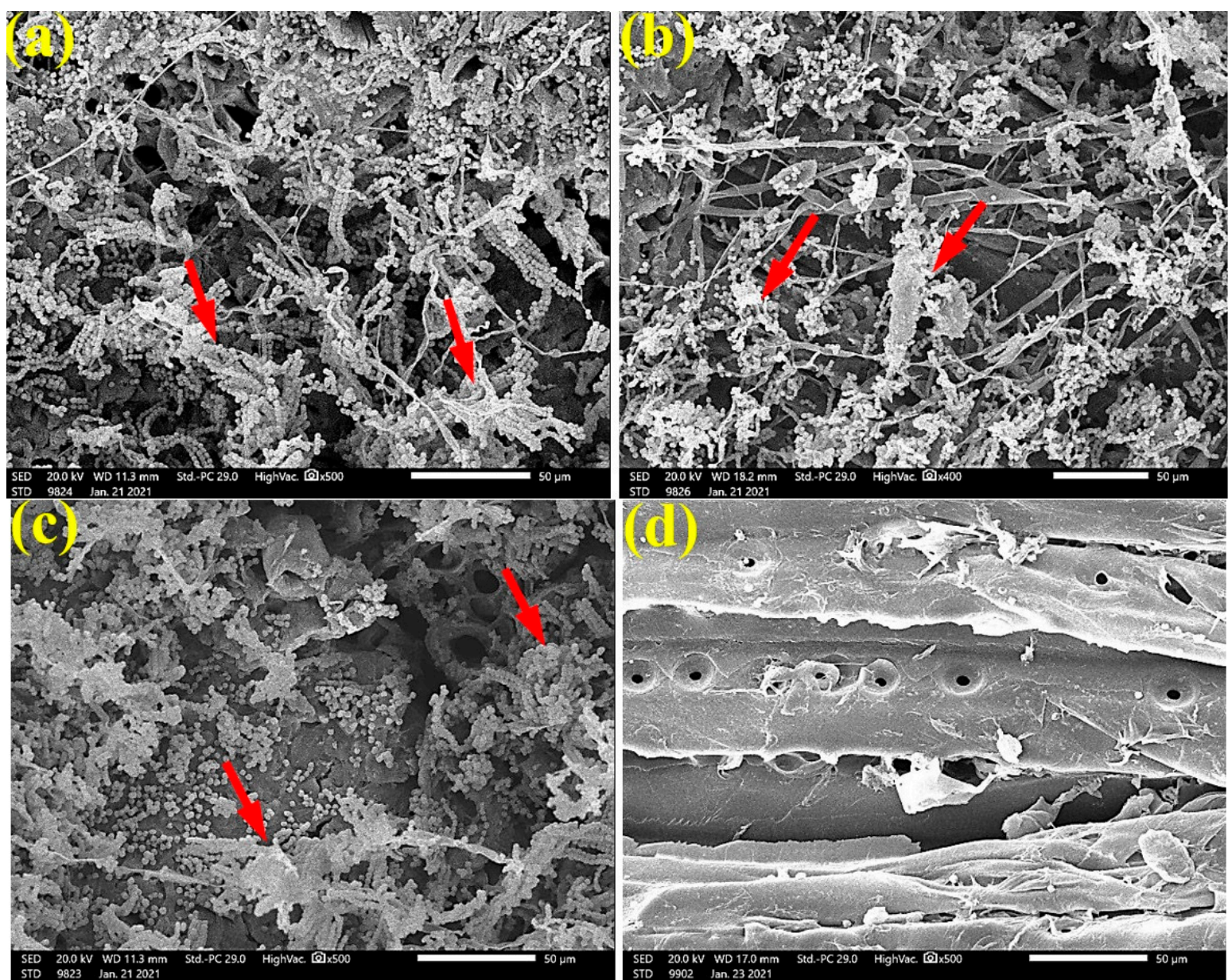

Figure 5. SEM images of P. roxburghii wood samples inoculated with Aspergillus fumigatus: (a) without treatment; (b) with $65 \mu \mathrm{L} / \mathrm{mL}$ C. reticulata EO; (c) with $65 \mu \mathrm{L} / \mathrm{mL}$ M. longifolia EO; (d) with $125 \mu \mathrm{L} / \mathrm{mL}$ M. longifolia EO. Arrows refer to the dense growth of fungal mycelia in wood samples, according to treatment.
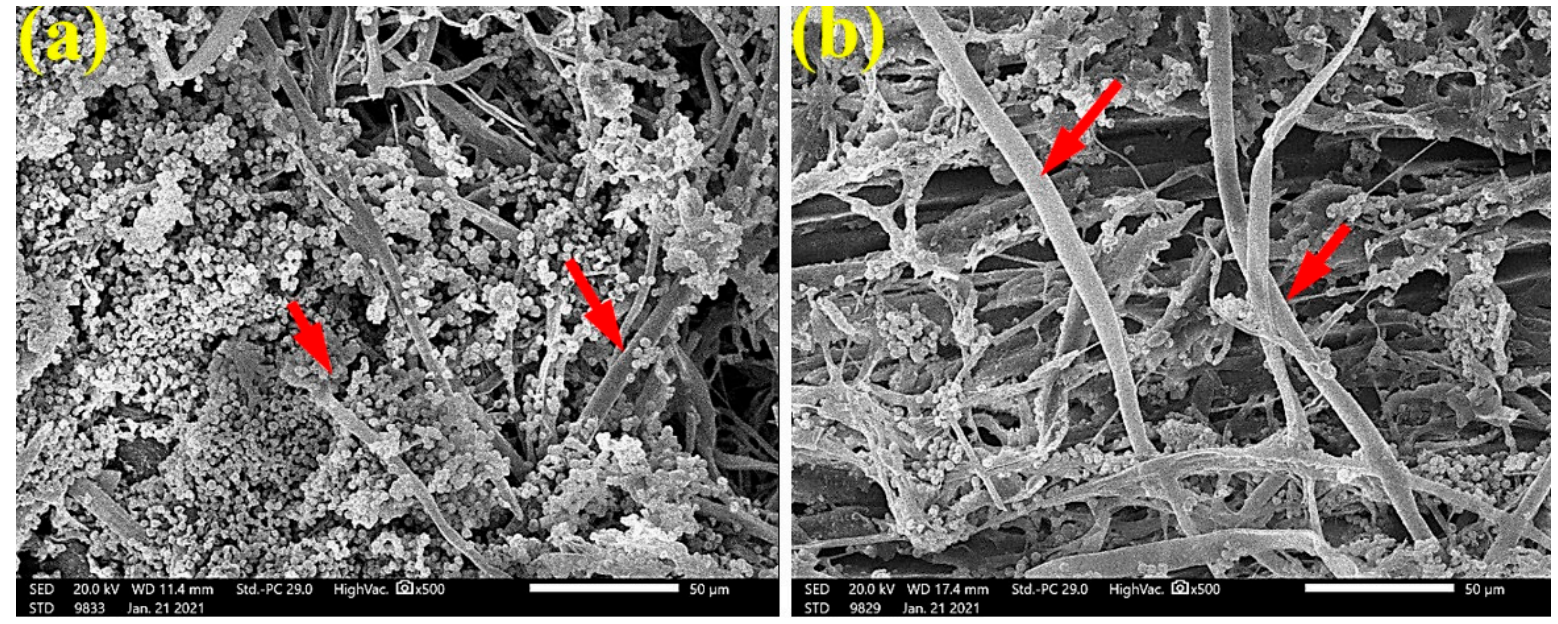

Figure 6. Cont. 

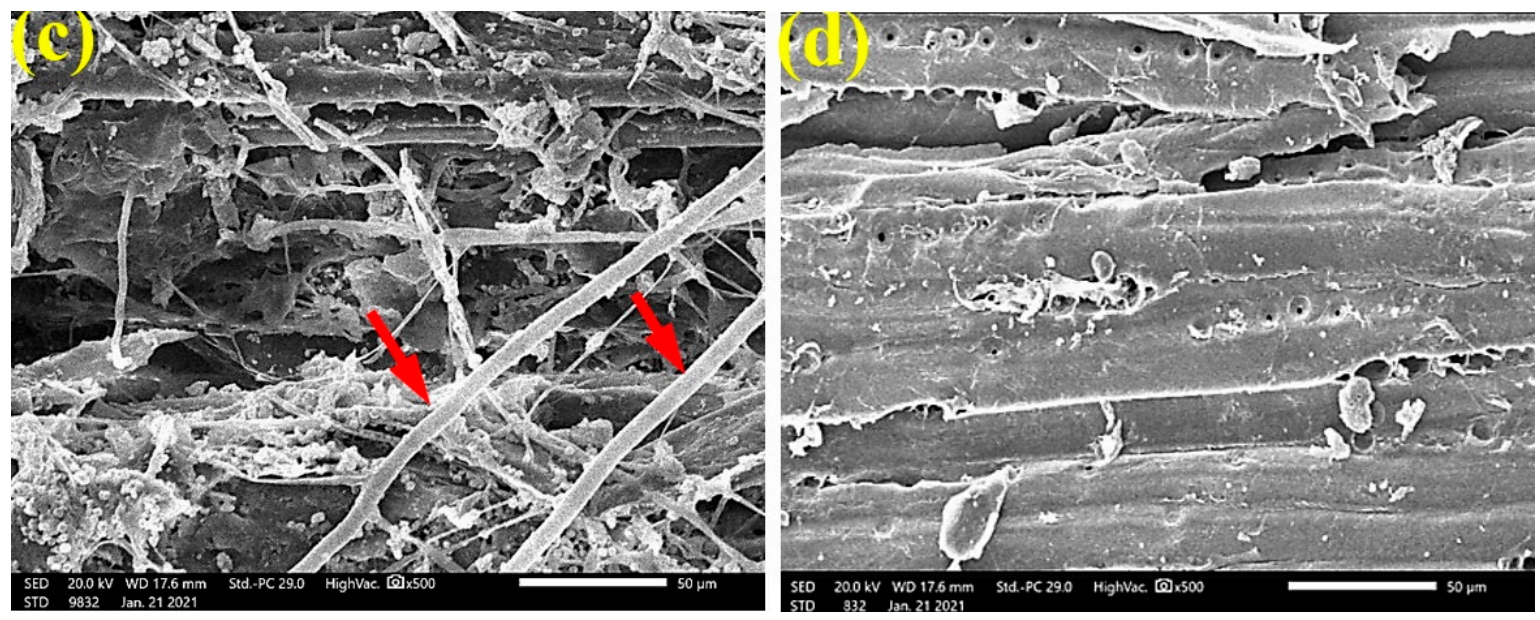

Figure 6. SEM images of $P$. roxburghii wood samples inoculated with $A$. niger: (a,b) without treatment; $(\mathbf{c})$ with $65 \mu \mathrm{L} / \mathrm{mL}$ M. longifolia EO; (d) with $125 \mu \mathrm{L} / \mathrm{mL}$ M. longifolia EO. Arrows refer to the dense growth of fungal mycelia in wood samples, according to treatment.

\section{Discussion}

M. longifolia aerial part EO shows the presence of menthone, eucalyptol (1,8-cineole), and pulegone as the main compounds. Chemical composition of the EO of M. longifolia grown around the world has shown different chymotypes. Menthone and iso-menthone have been found in the range amounts of $2.8-15.05 \%$ and $0.96-43.79 \%$, respectively, from the M. longifolia plants grown in Iran-Asia [55]. Menthone (10.7\%), pulegone (47.15\%), and 1,8cineole (11.54\%) have been found in M. longifolia plants grown in Tunisia [56], and menthol (19.4-32.5\%), menthone (20.7-28.8\%), 1,8-cineole (5.6-10.8\%), terpineol-4 (3.1-4.9\%), and pulegone (7.8-17.8\%) have been found in M. longifolia plants grown in Southern Africa [29]. In addition, in M. longifolia plants grown in Serbia, menthone (11.2\%) and piperitone $(8.8 \%)$ were identified as the main compounds [35]. The main compounds from M. longifolia plants growing in South Africa were menthone, eucalyptol, and pulegone [57]. Piperitone is the major compound (30.77\%), followed by eucalyptol (14.85\%) and caryophellene $(5.58 \%)$, in the EO of leaves from Saudi M. longifolia [37], while Desam et al. [58] reported that menthone (39.55\%), isopulegone (30.49\%), eucalyptol (10.38\%), and $\alpha$-terpineol $(3.15 \%)$ were major components from $M$. longifolia aerial parts that were air-dried under shade, with promising antibacterial activity against Staphylococcus aureus, Enterococcus faecalis, and Bacillus cereus and antifungal activity against Aspergillus flavus, A. fumigates, Alternaria alternaria, Fusarium oxyporum, and Penicillum spp.

Eucalyptol, found at $21.66 \%$ in M. longifolia EO, was also reported to be one of the major compounds in Mentha species EO, which ranged from $1.6 \%$ to $15.58 \%$ in plants from Iran [59-61], Tunisia [54,62] and Italy [63]. Pulegone, eucalyptol, and L-menthone, with percentages of $26.92 \%, 21.3 \%$, and $10.66 \%$, respectively, were found as the main compounds in the EO of plants grown in the winter season, while the main compounds found in the EO from the plants grown in spring were pulegone, oleic acid, and palmitic acid, with percentages of $38.2 \%, 23.79 \%$, and $15.26 \%$, respectively [32].

Other chymotypes were piperitenone oxide and piperitone oxide in plants growing in the Mediterranean region [27,60,63-65]. The M. longifolia plants growing in Iran [66] and Sudan [67] are rich in carvone, while the EOs from Jordan [65] and Tunisia [62] are rich in pulegone. Additionally, plants grown in Iran contain a eucalyptol-rich chemotype [59] or are rich in carveol [68]. M. longifolia EO from plants grown in Croatia showed the presence of piperitenone oxide, $\beta$-Caryophyllene, carvone, and limonene as the main compounds [69]. The EO from M. longifolia flowers collected from Zlatar, Belgrade, Serbia, showed the presence of trans- and cis-dihydrocarvone, piperitone, eucalyptol, and neoisodihydrocarveol as the main compounds, with $23.64 \%, 15.68 \%, 17.33 \%, 8.18 \%$, and $7.87 \%$, respectively [31]. Piperitone oxide, in high amounts, and piperitenon oxide were found 
in M. longifolia EO from Morocco [70], while cis-carveol was the dominant compound in M. longifolia from Iran, with percentages ranging from $53 \%$ to $78 \%$ [68]. Piperitone oxide and piperitenone oxide were found as the main compounds of the EO from the plants grown in Turkey [71]. From Iran, they were piperitone, limonene, and trans-piperitol [72]; from France, they were carvone, 1,8-cineole, and limonene [73]. The EO of M. longifolia growing wild in the Bahcesaray area (Van Province, Turkey) showed the presence of menthone $(19.31 \%)$, pulegone $(12.42 \%)$, piperitone $(11.05 \%)$, dihydrocarvon $(8.32 \%)$, limonene (6.1\%), 3-terpinolenone (5.66\%), eucalyptol (4.37\%), germacrene D (3.38\%), and caryopyllene (3.19\%) as the main components [74].

The plants grown in India, in different locations, showed the presence of piperitenone oxide, cis/trans-piperitone oxide, eucalyptol, piperitenone, dl-limonene, piperitone, 4hydroxy piperitone, and $\beta$-caryophyllene $[59,75-79]$. EOs, with their main compounds (carvone, limonene, and 1,6-dihydrocarveol) from plants grown in five regions (Saudi Arabia), showed moderate antifungal activity against $A$. niger, A. flavus, and F. solani [28]. At $250 \mathrm{ppm}$, the EO of $M$. longifolia inhibited the growth of $F$. oxysporum ( $92 \%)$, followed by Sclerotuim rolfsii (70.66\%) and Rhizoctonia solani (57.04\%) [75]. The EO from M. longifolia, at $10 \mu \mathrm{L} / \mathrm{mL}$, showed potent fungicidal activity against $A$. niger, A. ochraceus, A. flavus, A. versicolor, F. tricinctum, F. sporotrichioides, Penicillium funiculosum and Trichoderma viride [31].

Some previously reported bioactive compounds were found in the EO from C. reticulata, such as $\beta$-caryophyllene, $\beta$-caryophyllene oxide, $\beta$-elemene, $\gamma$-elemene, $\beta$-bisabolene, spathulenol, $\alpha$-caryophyllene, longifolene, $\gamma$-gurjunene, geranyl acetate, $\alpha$-bergamotene, linalyl acetate, germacrene D, nerol, D-limonene, and geraniol. Among some citrus EOs (Citrus lemon, C. reticulata, C. paradisi and C. sinensis), the EO from C. reticulata showed the lowest activity against Lactobacillus curvatus, L. sakei, Staphylococcus carnosus, S. xylosus, Enterobacter gergoviae and E. amnigenus [22]. Hydrocarbons and linalool were mostly found in leaf EO from C. reticulata, while thymol and/or terpinen-4-ol were found in leaf EO of some varieties $[80,81]$. In 41 mandarin cultivars, $\gamma$-terpinene, sabinene, linalool, limonene, $p$-cymene, $(E)$ - $\beta$-ocimene, $\beta$-pinene, and terpinen- 4 -ol were found in the range of $0.2-61.3 \%, 0.2-59.4 \%, 0.2-54.3 \%, 1.5-44.3 \%$, traces $-20.4 \%, 0.6-13.7 \%, 0.1-10.7 \%$, and $0.1-10.6 \%$, respectively, in the EO from leaves [40].

The EO from the peel of fully matured ripen fruits of $C$. reticulata Blanco, with its main compounds of limonene, geranial, neral, geranyl acetate, geraniol, $\beta$-caryophyllene, nerol, and neryl acetate) showed good activity against some pathogenic fungi, namely, Alternaria alternata, Rhizoctonia solani, Curvularia lunata, F. oxysporum, and Helminthosporium oryzae [41]. Mature fruit EO of C. reticulata showed the presence of citronellol, octanal, decanal, nonanal, $\beta$-pinene, limonene, citral, $\gamma$-terpinene, linalool, and $\alpha$-terpineol, with high antifungal activity against the growth of Penicillium italicum and P. digitatum [82]. Leaf EO from six cultivars of $C$. reticulata Blanco from Nigeria showed the presence of sabinene, $\gamma$-terpinene, $p$-cymene, $\delta$-3-carene, and $(E)$ - $\beta$-ocimene, while other constituents include linalool, myrcene, terpinen-4-ol, and cis-sabinenehydrate. In addition, limonene, terpinolene, $\beta$-pinene, $\alpha$-pinene, $\beta$-sinensal, and $\alpha$-sinensal were detected and isolated [38]. Geranial, neryl acetate, geranyl acetate, $\beta$-pinene, myrcene, neral, and $\beta$-caryophyllene have been identified in the leaf $\mathrm{EO}$ of $C$. limon [83].

The applied EOs from M. longifolia and C. reticulata to Pinus roxburghii wood showed good activity against the growth of A. flavus, A. niger, A. terreus and F. culmorum. Previously, EOs and extracts have been used as wood-biofungicides and have shown some potential antifungal activity, i.e., Acacia saligna wood treated with methanol extract from Maclura pomifera bark against Alternaria tenuissima [2] and A. saligna wood treated with Cupressus sempervirens methanolic extract against Trichoderma harzianum infestation [3]. Wood samples from P. sylvestris, P. rigida and Fagus sylvatica, treated with two EOs of P. rigida (wood) and Eucalyptus camaldulensis (leaves), showed promising antifungal activity against five molds (A. alternata, F. subglutinans, C. globosum, A. niger and T. viride) [50]. Wood samples from A. saligna, F. sylvatica, Juglans nigra and P. rigida, treated with the oil from Origanum majorana leaves, showed good antifungal activity against T. harzianum and A. niger without 
changing the wood structures [17]. Leucaena leucocephala wood, treated with Acer saccharum var. saccharum extract from inner or outer bark, in combination with citric acid, showed bioactivity against the growth of T. viride, F. subglutinans and A. niger [6]. Melia azedarach wood, treated with E. camaldulensis or V. agenus-castus n-hexane oily extracts, showed potential antifungal against F. culmorum, R. solani and P. chrysogenum [7]. M. azedarach wood samples, treated with $A$. saligna flower extract, showed promising antifungal activity against $P$. chrysogenum [4]. M. azedarach wood treated with Musa paradisiaca extract showed good bioactivity against F. culmorum and R. solani [5]. Chinaberry wood blocks, treated with E. camaldulensis bark extract, showed potential antifungal activity against F. culmorum and Botrytis cinerea [84], and M. azedarach wood treated with whole-plant extract of Haplophyllum tuberculatum showed good antifungal activity against F. culmorum and R. solani [85]. Corymbia citriodora EOs from leaves (the main compounds were citronellal, citronellol, and isopulegol) and fruits ( $\alpha$-pinene, eudesmol, limonene, $\gamma$-terpinene as main compounds), applied to wood samples at the amounts of 100, 50 and $25 \mu \mathrm{L}$, showed $100 \%$ inhibition against F. culmorum [18]. Recovered oil dissolved in $n$-hexane solvent, as partitioned from the distillate residue of hydrodistillation of fresh flowers from Matricaria chamomilla, showed potent bioactivity activity against $A$. niger and $A$. terreus [43].

To ensure the complete inhibition of fungal growth, SEM examinations showed a clear inhibition of the four studied fungi with the application oils at the concentration of $125 \mu \mathrm{L} / \mathrm{mL}$. The EOs might alter the hyphal morphology. Indeed, it can be seen from the SEM images that the fruiting bodies (conidiophores) are lower in number or do not exist, similar for spores, and the hyphae are altered.

\section{Conclusions}

The findings of the present research confirmed the potent antifungal activities of essential oils from Mentha longifolia (Saudi cultivar) and Citrus reticulata (Egyptian growing plant). Essential oils from $M$. longifolia and $C$. reticulata are of great interest with regard to their antifungal activities against Aspergillus flavus, A. niger, A. fumigatus, and Fusarium culmorum when applied as biopreservation for wood. Essential oil from M. longifolia, at $125 \mu \mathrm{L} / \mathrm{mL}$, applied to Pinus roxburghii wood, showed an inhibition zone $(7.33 \mathrm{~mm})$ around the wood samples when inoculated with A. flavus; the inhibition zone was $15.33 \mathrm{~mm}$ when the wood samples were treated with the essential oil from $C$. reticulata against $A$. fumigatus and $21.33 \mathrm{~mm}$ when treated with the oil from $M$. longifolia against $A$. niger. Additionally, both oils showed the lowest inhibition zones against F. culmorum when applied to wood samples. By SEM examination, wood anatomical features have been clearly shown to have no fungal growths when the wood samples were treated with both oils at $125 \mu \mathrm{L} / \mathrm{mL}$. These activities suggest their possible use as natural preservative additives and in the food industry.

Supplementary Materials: The following are available online at https:/ / www.mdpi.com/1996-1 944/14/6/1361/s1, Figure S1: Visual observation of Aspergillus flavus growth inhibition as affected by the EOs from (A) Mentha longifolia; (B) Citrus reticulata; (P) Positive control (Sertaconazol 3 g/L); (N) Negative control (DMSO 10\%), Figure S2: Visual observation of Aspergillus niger growth inhibition as affected by the EOs from (A) Mentha longifolia; (B) Citrus reticulata; (P) Positive control (Sertaconazol $3 \mathrm{~g} / \mathrm{L}$ ); (N) Negative control (DMSO 10\%), Figure S3: Visual observation of Aspergillus fumigatus growth inhibition as affected by the EOs from (A) Mentha longifolia; (B) Citrus reticulata; (P) Positive control (Sertaconazol $3 \mathrm{~g} / \mathrm{L}$ ); (N) Negative control (DMSO 10\%), Figure S4: Visual observation of Fusarium culmorum growth inhibition as affected by the EOs from (A) Mentha longifolia; (B) Citrus reticulata; (P) Positive control (Sertaconazol $3 \mathrm{~g} / \mathrm{L}$ ); (N) Negative control (DMSO 10\%).

Author Contributions: Conceptualization, methodology and formal analysis H.M.A., W.A.A.A.E., M.E.-H., M.Z.M.S. and A.S.T.; software, A.S.T., D.A.A.F., M.S.E. and A.A.H.; validation, M.Z.M.S., D.A.A.F., M.S.E., A.A.H. and E.M.A.-S. designed the experiment, conducted laboratory analyses, wrote parts of the manuscript, and interpreted the results. H.M.A., W.A.A.A.E., M.E.-H. and M.Z.M.S. contributed reagents and materials. H.M.A., W.A.A.A.E., M.E.-H., M.Z.M.S., A.S.T., D.A.A.F., M.S.E., A.A.H. and E.M.A.-S. visualized and revised the article. All authors have read and agreed to the published version of the manuscript. 
Funding: This research was supported by the Deanship of Scientific Research at King Saud University, which funded this work through Research Group No. RG 1435-011.

Institutional Review Board Statement: Not applicable.

Informed Consent Statement: Not applicable.

Data Availability Statement: The data presented in this study are available on request from the corresponding author.

Acknowledgments: The authors would like to extend their sincere appreciation to the Deanship of Scientific Research at King Saud University for funding this work through Research Group No. RG 1435-011.The authors would like to thank Mamoun S.M. Abd El-Kareem (Atomic and Molecular Physics Unit of the Experimental Nuclear Physics Department at the Nuclear Research Centre of the Egyptian Atomic Energy Authority, Inshas, Cairo, Egypt) for his sincere help in GC-MS and MNDO quantum chemical studies.

Conflicts of Interest: The authors declare no conflict of interest.

\section{References}

1. Barrios, M.J.; Medina, L.M.; Cordoba, M.G.; Jordano, R. Aflatoxin-producing strains of Aspergillus flavus isolated from cheese. J. Food Prot. 1997, 60, 192-194. [CrossRef]

2. Mansour, M.M.A.; Abdel-Megeed, A.; Nasser, R.A.; Salem, M.Z.M. Comparative evaluation of some woody tree methanolic extracts and Paraloid B-72 against phytopathogenic mold fungi Alternaria tenuissima and Fusarium culmorum. BioResources 2015, 10, 2570-2584. [CrossRef]

3. Mansour, M.M.A.; Salem, M.Z.M. Evaluation of wood treated with some natural extracts and Paraloid B-72 against the fungus Trichoderma harzianum: Wood elemental composition, in-vitro and application evidence. Int. Biodeterior. Biodegrad. 2015, 100, 62-69. [CrossRef]

4. Al-Huqail, A.A.; Behiry, S.I.; Salem, M.Z.M.; Ali, H.M.; Siddiqui, M.H.; Salem, A.Z.M. Antifungal, antibacterial, and antioxidant activities of Acacia saligna (Labill.) HL Wendl. flower extract: HPLC analysis of phenolic and flavonoid compounds. Molecules 2019, 24, 700. [CrossRef] [PubMed]

5. Behiry, S.I.; Okla, M.K.; Alamri, S.A.; El-Hefny, M.; Salem, M.Z.M.; Alaraidh, I.A.; Ali, H.M.; Al-Ghtani, S.M.; Monroy, J.C.; Salem, A.Z.M. Antifungal and antibacterial activities of Musa paradisiaca L. peel extract: HPLC analysis of phenolic and flavonoid contents. Processes 2019, 7, 215. [CrossRef]

6. Salem, M.Z.M.; Mansour, M.M.A.; Elansary, H.O. Evaluation of the effect of inner and outer bark extracts of Sugar Maple (Acer saccharum var. saccharum) in combination with citric acid against the growth of three common molds. J. Wood Chem. Technol. 2019, 39, 136-147. [CrossRef]

7. Salem, M.Z.M.; Behiry, S.I.; El-Hefny, M. Inhibition of Fusarium culmorum, Penicillium chrysogenum and Rhizoctonia solani by $n$-hexane extracts of three plant species as a wood-treated oil fungicide. J. Appl. Microbiol. 2019, 126, 1683-1699. [CrossRef] [PubMed]

8. Taha, A.S.; Salem, M.Z.M.; Abo Elgat, W.A.A.; Ali, H.M.; Hatamleh, A.A.; Abdel-Salam, E.M. Assessment of the Impact of Different Treatments on the Technological and Antifungal Properties of Papyrus (Cyperus Papyrus, L.) Sheets. Materials 2019, 12, 620. [CrossRef]

9. Taha, A.S.; Abo Elgat, W.A.A.; Salem, M.Z.M.; Ali, H.M.; Fares, Y.G.E.; Elshikh, M.S. Impact of some plant source additives on enhancing the properties and antifungal activities of pulp made from linen fibers. BioRes. 2019, 14, 6025-6046. [CrossRef]

10. Abo Elgat, W.A.A.; Taha, A.S.; Böhm, M.; Vejmelková, E.; Mohamed, W.S.; Fares, Y.G.; Salem, M.Z.M. Evaluation of the mechanical, physical, and anti-fungal properties of flax laboratory papersheets with the nanoparticles treatment. Materials 2020, 13, 363. [CrossRef]

11. Salem, M.Z.M.; Abo Elgat, W.A.A.; Taha, A.S.; Fares, Y.G.; Ali, H.M. Impact of three natural oily extracts as pulp additives on the mechanical, optical, and antifungal properties of paper sheets made from Eucalyptus camaldulensis and Meryta sinclairii wood branches. Materials 2020, 13, 1292. [CrossRef] [PubMed]

12. Hussein, H.S.; Salem, M.Z.M.; Soliman, A.M. Repellent, attractive, and insecticidal effects of essential oils from Schinus terebinthifolius fruits and Corymbia citriodora leaves on two whitefly species, Bemisia tabaci and Trialeurodes ricini. Sci. Horticul. 2017, 216, 111-119. [CrossRef]

13. Salem, M.Z.M.; EL-Hefny, M.; Nasser, R.A.; Ali, H.M.; El-Shanhorey, N.A.; Elansary, H.O. Medicinal and biological values of Callistemon viminalis extracts: History, current situation and prospects. Asian Pac. J. Trop. Med. 2017, 10, 229-237. [CrossRef]

14. Ashmawy, N.A.; Al Farraj, D.A.; Salem, M.Z.M.; Elshikh, M.S.; Al-Kufaidy, R.; Alshammari, M.K.; Salem, A.Z.M. Potential impacts of Pinus halepensis Miller trees as a source of phytochemical compounds: Antibacterial activity of the cones essential oil and n-butanol extract. Agrofores. Syst. 2020, 94, 1403-1413. [CrossRef] 
15. Abdelsalam, N.R.; Salem, M.Z.M.; Ali, H.M.; Mackled, M.I.; EL-Hefny, M.; Elshikh, M.S.; Hatamleh, A.A. Morphological, biochemical, molecular, and oil toxicity properties of Taxodium trees from different locations. Ind. Crops Prod. 2019, $139,111515$. [CrossRef]

16. El-Sabrout, A.M.; Salem, M.Z.M.; Bin-Jumah, M.; Allam, A.A. Toxicological activity of some plant essential oils against Tribolium castaneum and Culex pipiens larvae. Processes 2019, 7, 933. [CrossRef]

17. Salem, M.Z.M.; Hamed, S.A.M.; Mansour, M.M.A. Assessment of efficacy and effectiveness of some extracted bio-chemicals as bio-fungicides on Wood. Drv. Indu. 2019, 70, 337-350. [CrossRef]

18. Behiry, S.I.; Nasser, R.A.; Abd El-Kareem, M.S.M.; Ali, H.M.; Salem, M.Z.M. Mass Spectroscopic Analysis, MNDO Quantum Chemical Studies and Antifungal Activity of Essential and Recovered Oil Constituents of Lemon-Scented Gum against Three Common Molds. Processes 2020, 8, 275. [CrossRef]

19. Mohamed, A.A.; Behiry, S.I.; Ali, H.M.; EL-Hefny, M.; Salem, M.Z.M.; Ashmawy, N.A. Phytochemical Compounds of Branches from P. halepensis Oily Liquid Extract and S. terebinthifolius Essential Oil and Their Potential Antifungal Activity. Processes 2020, 8, 330. [CrossRef]

20. Mohamed, A.A.; EL-Hefny, M.; El-Shanhorey, N.A.; Ali, H.M. Foliar Application of Bio-Stimulants Enhancing the Production and the Toxicity of Origanum majorana Essential Oils Against Four Rice Seed-Borne Fungi. Molecules 2020, 25, 2363. [CrossRef]

21. Okla, M.K.; Alamri, S.A.; Salem, M.Z.M.; Ali, H.M.; Behiry, S.I.; Nasser, R.A.; Soufan, W. Yield, Phytochemical Constituents, and Antibacterial Activity of Essential Oils from the Leaves/Twigs, Branches, Branch Wood, and Branch Bark of Sour Orange (Citrus aurantium L.). Processes 2019, 7, 363. [CrossRef]

22. Viuda-Martos, M.; Ruiz-Navajas, Y.; Fernandez-Lopez, J.; Perez-Álvarez, J. Antibacterial activity of lemon (Citrus lemon L.), mandarin (Citrus reticulata L.), grapefruit (Citrus paradisi L.) and orange (Citrus sinensis L.) essential oils. J. Food Saf. 2008, 28, 567-576. [CrossRef]

23. Atarés, L.; Chiralt, A. Essential oils as additives in biodegradable films and coatings for active food packaging. Trend. Food Sci. Technol. 2016, 48, 51-62. [CrossRef]

24. Rodriguez-Garcia, I.; Silva-Espinoza, B.A.; Ortega-Ramirez, L.A.; Leyva, J.M.; Siddiqui, M.W.; Cruz-Valenzuela, M.R.; GonzalezAguilar, G.A.; Ayala-Zavala, J.F. Oregano essential oil as an antimicrobial and antioxidant additive in food products. Crit. Rev. Food Sci. Nutr. 2016, 56, 1717-1727. [CrossRef]

25. Nieto, G. Biological activities of three essential oils of the Lamiaceae family. Medicines 2017, 4, 63. [CrossRef]

26. Gulluce, M.; Sahin, F.; Sokmen, M.Ü.N.E.V.V.E.R.; Ozer, H.; Daferera, D.; Sokmen, A.T.A.L.A.Y.; Polissiou, M.; Adiguzel, A.Y.Ş.E.; Ozkan, H.İ.C.A.B.İ. Antimicrobial and antioxidant properties of the essential oils and methanol extract from Mentha longifolia L. ssp. longifolia. Food Chem. 2007, 103, 1449-1456. [CrossRef]

27. Nikšić, H.; Kovač-Bešović, E.; Makarević, E.; Durić, K. Chemical composition, antimicrobial and antioxidant properties of Mentha longifolia (L.) Huds. essential oil. J. Heal. Sci. 2012, 2, 192-200. [CrossRef]

28. Anwar, F.; Alkharfy, K.M.; Najeeb-ur-Rehman Adam, E.H.K.; Gilani, A.U.H. Chemo-geographical variations in the composition of volatiles and the biological attributes of Mentha longifolia (L.) essential oils from Saudi Arabia. Int. J. Pharmacol. 2017, 13, 408-424. [CrossRef]

29. Viljoen, A.M.; Petkar, S.; Van Vuuren, S.F.; Figueiredo, A.C.; Pedro, L.G.; Barroso, J.G. The chemo-geographical variation in essential oil composition and the antimicrobial properties of Wild mint-Mentha longifolia sub sp. polyadena (Lamiaceae) in Southern Africa. J. Essen. Oil Res. 2006, 18, 60-65. [CrossRef]

30. Mikaili, P.; Mojaverrostami, S.; Moloudizargari, M.; Aghajanshakeri, S. Pharmacological and therapeutic effects of Mentha longifolia L. and its main constituent, menthol. Anci. Sci. Life 2013, 33, 131-138. [CrossRef]

31. Džamić, A.M.; Soković, M.D.; Ristić, M.S.; Novaković, M.; Grujić-Jovanović, S.; Tešević, V.; Marin, P.D. Antifungal and antioxidant activity of Mentha longifolia (L.) Hudson (Lamiaceae) essential oil. Bot. Serb. 2010, 34, 57-61.

32. Zouari-Bouassida, K.; Trigui, M.; Makni, S.; Jlaiel, L.; Tounsi, S. Seasonal variation in essential oils composition and the biological and pharmaceutical protective effects of Mentha longifolia leaves grown in Tunisia. BioMed Res. Int. 2018, 2018, 7856517. [CrossRef]

33. Tafrihi, M.; Imran, M.; Tufail, T.; Gondal, T.A.; Caruso, G.; Sharma, S.; Sharma, R.; Atanassova, M.; Atanassov, L.; Valere Tsouh Fokou, P.; et al. The Wonderful Activities of the Genus Mentha: Not Only Antioxidant Properties. Molecules 2021, $26,1118$. [CrossRef] [PubMed]

34. Stanisavljević, D.; Đorđević, S.; Milenković, M.; Lazić, M.; Veličković, D.; Ranđelović, N.; Zlatković, B. Antimicrobial and antioxidant activity of the essential oils obtained from Mentha longifolia L. Hudson, dried by three different techniques. Rec. Nat. Prod. 2014, 8, 61-65.

35. Mimica-Dukić, N.; Božin, B.; Soković, M.; Mihajlović, B.; Matavulj, M. Antimicrobial and antioxidant activities of three Mentha species essential oils. Planta Med. 2003, 69, 413-419. [CrossRef]

36. Dehghanpour-Farashah, S.; Taheri, P. Antifungal and antiaflatoxigenic effects of Mentha longifolia essential oil against Aspergillus flavus. Int. J. New Technol. Res. 2016, 2, 30-39.

37. Burham, B.O.; Osman, O.A.; Nour, A.A.M. Chemical composition and antibacterial activity of essential oil of Mentha longifolia Leaf from Albaha Area Southern Saudi Arabia. Asian J. Biol. Life Sci. 2019, 8, 48-52. [CrossRef]

38. Kasali, A.A.; Lawal, O.A.; Abanikannda, O.T.; Olaniyan, A.A.; Setzer, W.N. Citrus Essential Oil of Nigeria Part IV: Volatile Constituents of Leaf Oils of Mandarins (Citrus Reticulata Blanco) from Nigeria. Rec. Nat. Prod. 2010, 4, 156-162. 
39. Wu, T.; Cheng, D.; He, M.; Pan, S.; Yao, X.; Xu, X. Antifungal action and inhibitory mechanism of polymethoxylated flavones from Citrus reticulata Blanco peel against Aspergillus niger. Food Cont. 2014, 35, 354-359. [CrossRef]

40. Lota, M.L.; Serra, D.R.; Tomi, F.; Casanova, J. Chemical variability of peel and leaf essential oils of mandarins from Citrus reticulata Blanco. Biochem. Syst. Ecol. 2000, 28, 61-78. [CrossRef]

41. Chutia, M.; Bhuyan, P.D.; Pathak, M.G.; Sarma, T.C.; Boruah, P. Antifungal activity and chemical composition of Citrus reticulata Blanco essential oil against phytopathogens from North East India. LWT-Food Sci. Technol. 2009, 42, 777-780. [CrossRef]

42. Njoroge, S.M.; Munga, H.N.; Koaze, H.; Phi, N.T.L.; Sawamura, M.J. Volatile constituents of mandarin Citrus reticulata Blanco peel oil from Burundi. Essent. Oil Res. 2006, 18, 659-662. [CrossRef]

43. EL-Hefny, M.; Abo Elgat, W.A.A.; Al-Huqail, A.A.; Ali, H.M. Essential and recovery oils from Matricaria chamomilla flowers as environmentally friendly fungicides against four fungi isolated from cultural heritage objects. Processes 2019, 7, 809. [CrossRef]

44. Salem, M.Z.M.; Elansary, H.O.; Ali, H.M.; El-Settawy, A.A.; Elshikh, M.S.; Abdel-Salam, E.M.; Skalicka-Woźniak, K. Antibacterial, antifungal, and antioxidant activities of essential oils extracted from Cupressus macrocarpa branchlets and Corymbia citriodora leaves grown in Egypt. BMC Complem. Alter. Med. 2018, 18, 23. [CrossRef]

45. Ashmawy, N.A.; Behiry, S.I.; Al-Huqail, A.A.; Ali, H.M.; Salem, M.Z.M. Bioactivity of Selected Phenolic Acids and Hexane Extracts from Bougainvilla spectabilis and Citharexylum spinosum on the Growth of Pectobacterium carotovorum and Dickeya solani Bacteria: An Opportunity to Save the Environment. Processes 2020, 8, 482. [CrossRef]

46. EL-Hefny, M.; Salem, M.Z.M.; Behiry, S.I.; Ali, H.M. The Potential Antibacterial and Antifungal Activities of Wood Treated with Withania somnifera Fruit Extract, and the Phenolic, Caffeine, and Flavonoid Composition of the Extract According to HPLC. Processes 2020, 8, 113. [CrossRef]

47. Salem, M.Z.M.; Mansour, M.M.A.; Mohamed, W.S.; Ali, H.M.; Hatamleh, A.A. Evaluation of the antifungal activity of treated Acacia saligna wood with Paraloid B-72/ $\mathrm{TiO}_{2}$ nanocomposites against the growth of Alternaria tenuissima, Trichoderma harzianum, and Fusarium culmorum. BioResources 2017, 12, 7615-7627. [CrossRef]

48. Lopez, P.; Sanchez, C.; Batlle, R.; Nerin, C. Solid- and vapor-phase antimicrobial activities of six essential oils: Susceptibility of selected foodborne bacterial and fungal strains. J. Agric. Food Chem. 2005, 53, 6939-6946. [CrossRef] [PubMed]

49. Nedorostova, L.; Kloucek, P.; Kokoska, L.; Stolcova, M.; Pulkrabek, J. Antimicrobial properties of selected essential oils in vapour phase against foodborne bacteria. Food Cont. 2009, 20, 157-160. [CrossRef]

50. Salem, M.Z.M.; Zidan, Y.E.; Mansour, M.M.A.; El Hadidi, N.M.N.; Abo Elgat, W.A.A. Antifungal activities of two essential oils used in the treatment of three commercial woods deteriorated by five common mold fungi. Int. Biodeterior. Biodegrad. 2016, 106, 88-96. [CrossRef]

51. Salem, M.Z.M. EDX measurements and SEM examination of surface of some imported woods inoculated by three mold fungi. Measurement 2016, 86, 301-309. [CrossRef]

52. Abd El-Kareem, M.S.M.; El-desawy, M.; Hawash, M.F.; Fahmey, M.A. Structural investigation of sparfloxacin drug using mass spectrometry and MNDO semi-empirical molecular orbital calculations. Int. J. Adv. Chem. 2018, 6, 74-78. [CrossRef]

53. Abd El-Kareem, M.S.M.; Selim, E.T.M. Semi-empirical and HOMO, LUMO studies of some chlorinated pesticides compounds. Commun. Comput. Chem. 2018, 6, 1-12. [CrossRef]

54. SAS. User Guide: Statistics (Release 8.02); SAS Institute: Cary, NC, USA, 2001.

55. Jamzad, M.; Jamzad, Z.; Mokhber, F.; Ziareh, S.; Yari, M. Variation in essential oil composition of Mentha longifolia var. chlorodichtya Rech. f. and Ziziphora clinopodiodes Lam. growing in different habitats. J. Med. Plants Res. 2013, 7, 1618-1623. [CrossRef]

56. Hajlaouli, H.; Snoussi, M.; Jannet, H.B.; Mighri, Z.; Bakhrouf, A. Comparison of chemical composition and antimicrobial activities of Mentha longifolia L. spp. Longifolia essential oil from two Tunisian localities (Gabes and Sidi Bouzid). Ann. Microbiol. 2008, 58, 513-520. [CrossRef]

57. Oyedeji, A.O.; Afolayan, A.J. Chemical composition and antibacterial activity of the essential oil isolated from South African Mentha longifolia (L.) L. subsp. Capensis (Th unb.) Briq. J. Essent. Oil Res. 2006, 18, 57-60. [CrossRef]

58. Desam, N.R.; Al-Rajab, A.J.; Sharma, M.; Mylabathula, M.M.; Gowkanapalli, R.R.; Mohammed, A. Chemical composition, antibacterial and antifungal activities of Saudi Arabian Mentha longifolia L. essential oil. J. Coast. Life Med. 2017, 5, 441-446. [CrossRef]

59. Golparvar, A.R.; Hadipanah, A.; Gheisari, M.M.; Salehi, S.; Khaliliazar, R.; Ghasemi, O. Comparative analysis of chemical composition of Mentha longifolia (L.) Huds. J. Herbal. Drugs 2017, 7, 235-241.

60. Rezaei, M.B.; Jaymand, K.; Jamzad, Z. Chemical constituents of Mentha longifolia (L.) Hudson var. chlorodictya Rech. f. from three different localities. Pajouh. Sazand. 2000, 13, 60-63.

61. Barzin, G.; Mazooji, A.; Salimpour, F. Essential oil composition of four varieties of Mentha Longifolia L. From northern parts of Iran. Int. J. Pl. An. Env. Sci. 2014, 4, 639-643.

62. Mkaddem, M.; Bouajila, J.; Ennajar, M.; Lebrihi, A.; Mathieu, F.; Romdhane, M. Chemical composition and antimicrobial and antioxidant activities of Mentha longifolia L. and viridis) essential oils. J. Food Sci. 2009, 74, M358-M363. [CrossRef]

63. Maffei, M. A chemotype of Mentha longifolia (L.) Hudson particularly rich in piperitenone oxide. Flav. Fragr. J. 1988, 3, 23-26. [CrossRef] 
64. Sharipova, F.S.; Elchibekova, L.A.; Nedeko, E.S.; Gusak, L.E. Wild mints of Kazakhstan. II. Study of the chemical composition of Mentha arvensis L., Mentha longifolia (L.) Hudson, Mentha crispa L. and Mentha interrupta essential oils. SSR J. Ser. Khimiya 1983, $4,67-71$.

65. Fleisher, Z.; Fleisher, A. Volatile extract of Mentha longifolia growing in Israel. Aromatic plants of the Holy Land and the Sinai. Part XIII. J. Essen. Oil Res. 1998, 10, 647-648. [CrossRef]

66. Monfared, A.; Nabid, M.R.; Rustaiyan, A. Composition of a carvone chemotype of Mentha longifolia (L.) Huds. from Iran. J. Essen. Oil Res. 2002, 14, 51-52. [CrossRef]

67. Younis, Y.M.H.; Basher, S.M. Carvone-rich essential oils from Mentha longifolia (L.) Huds. ssp. schimperi Briq. and Mentha spicata L. grown in Sudan. J. Essen. Oil Res. 2004, 16, 539-541. [CrossRef]

68. Zeinali, H.; Arzani, A.; Razmjoo, K.; Rezaee, M.B. Evaluation of oil compositions of Iranian mints (Mentha ssp.). J. Essen. Oil Res. 2005, 17, 156-159. [CrossRef]

69. Mastelic, J.; Jerkovic, I. Free and glycosidically bound volatiles of Mentha longifolia growing in Croatia. Chem. Nat. Comp. 2002, 38, 561-564. [CrossRef]

70. Ghoulami, S.; Idrissi, A.I.; Fkih-Tetouani, S. Phytochemical study of Mentha longifolia of Morocco. Fitoterapia 2001, 72, 596-598. [CrossRef]

71. Baser, K.H.C.; Kurkcuglu, M.; Tarimcila, G.; Kaynak, G. Essential oils of Mentha species from northern Turkey. J. Essen. Oil Res. 1999, 11, 579-588. [CrossRef]

72. Rasooli, I.; Rezaei, M.B. Bioactivity and chemical properties of essential oils from Zataria multifl ora Boiss and Mentha longifolia (L.) Huds. J. Essent. Oil Res. 2002, 14, 141-146. [CrossRef]

73. Vidal, J.P.; Noleau, I.; Bertholon, G.; Lamy, J.; Richard, H. Constituants volatils des huiles essentielles de Menthes sylvestres de la Drome. Parf. Cosm. Aromes 1985, 64, 83-87.

74. Okut, N.; Yagmur, M.; Selcuk, N.; Yildirim, B. Chemical composition of essential oil of Mentha longifolia L. Subsp. Longifolia growing wild. Pak. J. Bot. 2017, 49, 525-529.

75. Singh, P.; Kumar, R.; Prakash, O.; Kumar, M.; Pant, A.K.; Isidorov, V.A.; Szczepaniak, L. Reinvestigation of Chemical Composition, Pharmacological, Antibacterial and Fungicidal Activity of Essential oil from Mentha longifolia (L.) Huds. Res. J. Phytochem. 2017, 11, 129-141. [CrossRef]

76. Singh, H.P.; Batish, D.R.; Mittal, S.; Dogra, K.S.; Yadav, S.; Kohli, R.K. Constituents of leaf essential oil of Mentha longifolia from India. Chem. Nat. Compd. 2008, 44, 528-529. [CrossRef]

77. Methella, C.S.; Shah, G.C.; Melkani, A.B.; Pant, A.K. Terpenoids of Mentha longifolia himalaiensis. Fitoterapia 1989, 60, 349-350.

78. Kharakwal, H.; Shah, G.C.; Mathela, C.S.; Laurent, R. Variation in the terpenoid composition of Mentha longifolia subsp. himalaiensis. Ind. Perfum. 1994, 38, 29-32.

79. Verma, R.S.; Pandey, V.; Chauhan, A.; Tiwari, R. Essential oil composition of Mentha longifolia (L.) L. collected from Garhwal region of Western-Himalaya. J. Essen. Oil Bear. Plants 2015, 18, 957-966. [CrossRef]

80. Fleisher, Z.; Fleisher, A. Mandarin Leaf Oil (Citrus reticulata Blanco) Aromatic Plants of the Holy Land and the Sinai. Part III. J. Essen. Oil Res. 1990, 2, 331-334. [CrossRef]

81. Fleisher, Z.; Fleisher, A. Citrus petitgrain oils of Israel. Perfum. Favor. 1991, 6, $43-47$.

82. Tao, N.; Jia, L.; Zhou, H. Anti-fungal activity of Citrus reticulata Blanco essential oil against Penicillium italicum and Penicillium digitatum. Food Chem. 2014, 153, 265-271. [CrossRef] [PubMed]

83. Vekiari, S.A.; Protopapadakis, E.E.; Papadopoulou, P.; Papanicolaou, D.; Panou, C.; Vamvakias, M. Composition and seasonal variation of the essential oil from leaves and peel of a Cretan lemon variety. J. Agric. Food Chem. 2002, 50, 147-153. [CrossRef] [PubMed]

84. Abdelkhalek, A.; Salem, M.Z.M.; Kordy, A.M.; Salem, A.Z.M.; Behiry, S.I. Antiviral, antifungal, and insecticidal activities of Eucalyptus bark extract: HPLC analysis of polyphenolic compounds. Microb. Pathogen. 2020, 147, 104383. [CrossRef] [PubMed]

85. Abdelkhalek, A.; Salem, M.Z.M.; Hafez, E.; Behiry, S.I.; Qari, S.H. The Phytochemical, Antifungal, and First Report of the Antiviral Properties of Egyptian Haplophyllum tuberculatum Extract. Biology 2020, 9, 248. [CrossRef] 